
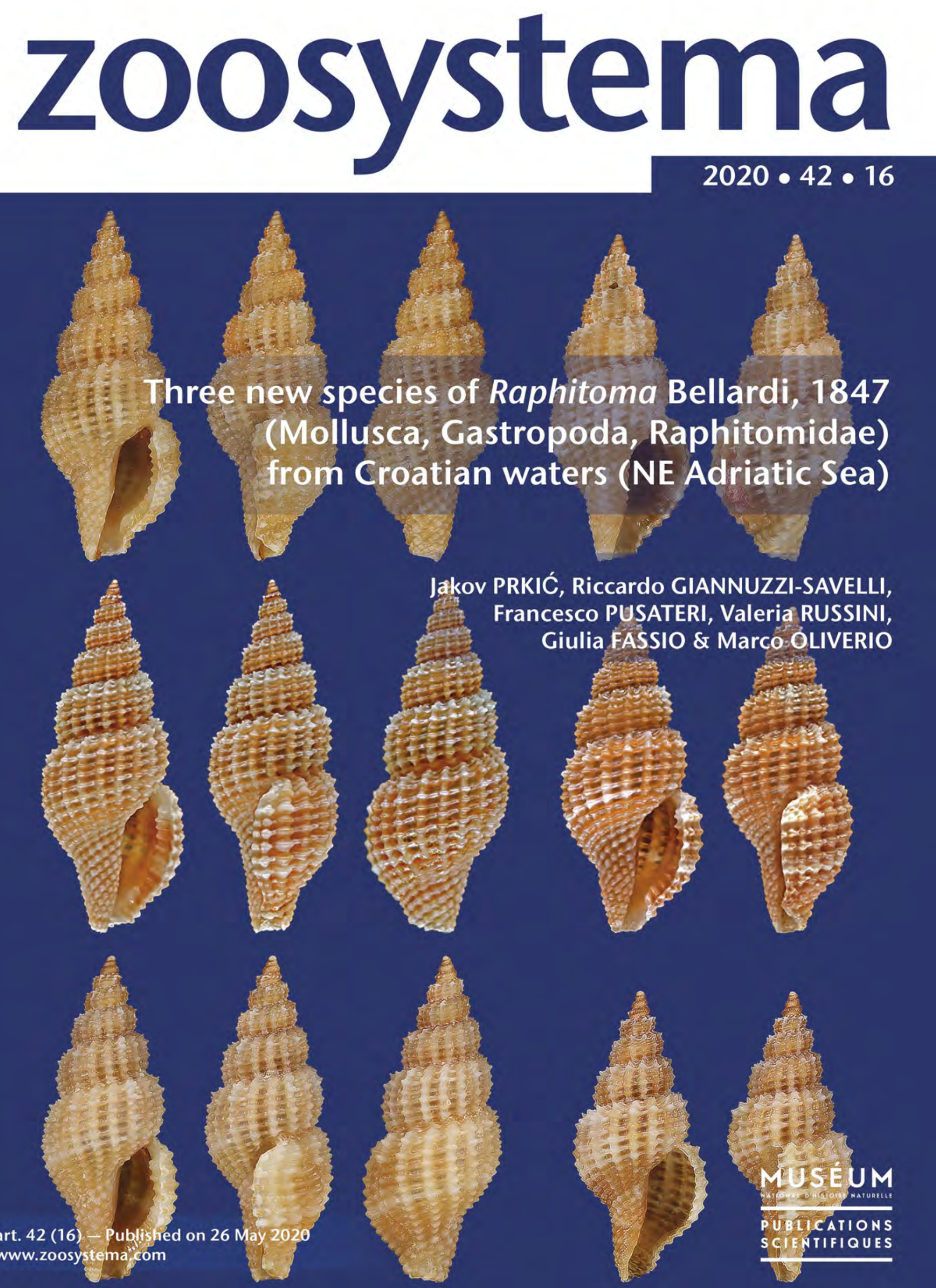
Directeur de LA publication / Publication diRECTOR: Bruno David

Président du Muséum national d'Histoire naturelle

RÉDACTRICE EN CHEF / EDITOR-IN-CHIEF: Laure Desutter-Grandcolas

AssistANT DE RÉDACTION / AsSISTANT EDITOR: Anne Mabille (zoosyst@mnhn.fr)

Mise en PAge / Page Layout: Anne Mabille

COMITÉ SCIENTIFIQUE / SCIENTIFIC BOARD:

James Carpenter (AMNH, New York, États-Unis)

Maria Marta Cigliano (Museo de La Plata, La Plata, Argentine)

Henrik Enghoff (NHMD, Copenhague, Danemark)

Rafael Marquez (CSIC, Madrid, Espagne)

Peter $\mathrm{Ng}$ (University of Singapore)

Norman I. Platnick (AMNH, New York, États-Unis)

Jean-Yves Rasplus (INRA, Montferrier-sur-Lez, France)

Jean-François Silvain (IRD, Gif-sur-Yvette, France)

Wanda M. Weiner (Polish Academy of Sciences, Cracovie, Pologne)

John Wenzel (The Ohio State University, Columbus, États-Unis)

COUVERTURE / COVER:

Shells of Raphitoma pusaterii Prkić \& Giannuzzi-Savelli n. sp., Mljet Island.

Zoosystema est indexé dans / Zoosystema is indexed in:

- Science Citation Index Expanded (SciSearch ${ }^{\circledR}$ )

- ISI Alerting Services ${ }^{\circledR}$

- Current Contents ${ }^{\circledR} /$ Agriculture, Biology, and Environmental Sciences ${ }^{\circledR}$

- Scopus ${ }^{\circledR}$

Zoosystema est distribué en version électronique par / Zoosystema is distributed electronically by:

- BioOne ${ }^{\circledR}$ (http://www.bioone.org)

Les articles ainsi que les nouveautés nomenclaturales publiés dans Zoosystema sont référencés par / Articles and nomenclatural novelties published in Zoosystema are referenced by:

- ZooBank ${ }^{\circledR}$ (http://zoobank.org)

Zoosystema est une revue en flux continu publiée par les Publications scientifiques du Muséum, Paris / Zoosystema is a fast track journal published by the Museum Science Press, Paris

Les Publications scientifiques du Muséum publient aussi / The Museum Science Press also publish:

Adansonia, Geodiversitas, Anthropozoologica, European Journal of Taxonomy, Naturae, Cryptogamie sous-sections Algologie, Bryologie, Mycologie.

Diffusion - Publications scientifiques Muséum national d'Histoire naturelle

CP 41 - 57 rue Cuvier F-75231 Paris cedex 05 (France)

Tél. : 33 (0)1 40794805 / Fax: 33 (0)1 40793840

diff.pub@mnhn.fr / http://sciencepress.mnhn.fr

(C) Publications scientifiques du Muséum national d'Histoire naturelle, Paris, 2020

ISSN (imprimé / print): 1280-9551/ ISSN (électronique / electronic): 1638-9387 


\title{
Three new species of Raphitoma Bellardi, 1847 (Mollusca, Gastropoda, Raphitomidae) from Croatian waters (NE Adriatic Sea)
}

\author{
Jakov PRKIĆ \\ Getaldićeva 11, C-21000 Split (Croatia) \\ jakov.prkic1@inet.hr \\ Riccardo GIANNUZZI-SAVELLI \\ Via Mater Dolorosa 54, I-90146 Palermo (Italy) \\ malakos@tin.it (corresponding author) \\ Francesco PUSATERI \\ Via Castellana 64, I-90135 Palermo (Italy) \\ francesco@pusateri.it \\ Valeria RUSSINI \\ Giulia FASSIO \\ Marco OLIVERIO
}

Department of Biology and Biotechnologies "Charles Darwin", Sapienza University of Rome, Viale dell'Università 32, I-00185 Rome (Italy) valeria.russini@uniroma1.it, giulia.fassio@uniroma1.it, marco.oliverio@uniroma1.it

Submitted on 9 July 2019 | Accepted on 2 December 2019 | Published on 26 May 2020

KEY WORDS

Raphitoma,

Adriatic Sea new species.
Prkić J., Giannuzzi-Savelli R., Pusateri F., Russini V., Fassio G. \& Oliverio M. 2020. - Three new species of Raphitoma Bellardi, 1847 (Mollusca, Gastropoda, Raphitomidae) from Croatian waters (NE Adriatic Sea). Zoosystema 42 (16): 215-237. https://doi.org/10.5252/zoosystema2020v42a16. http://zoosystema.com/42/16

\section{ABSTRACT}

Three new species of the neogastropod family Raphitomidae Bellardi, 1875, are described from the Croatian waters of the Adriatic Sea: Raphitoma petanii Prkić, Giannuzzi-Savelli \& Pusateri n. sp., $R$. pusaterii Prkić \& Giannuzzi-Savelli n. sp. and R. stanici Prkić, Giannuzzi-Savelli \& Pusateri n. sp. The new species are diagnosed by teleoconch characters and by genetic data (COI sequences) in an integrative taxonomy framework. They belong to a group of species with microgranules on the external surface of all teleoconch whorls and all three have a multispiral protoconch indicating a planktotrophic larval phase. The first two species are so far known only from material found in Croatia. $R$. petanii Prkić, Giannuzzi-Savelli \& Pusateri n. sp. and $R$. stanici Prkić, Giannuzzi-Savelli \& Pusateri n. sp. are predominantly shallow-water species, whereas $R$. pusaterii Prkić \& Giannuzzi-Savelli n. sp. has been so far collected only from deeper bottoms with presence of the red coral, Corallium rubrum (Linnaeus, 1758). Syntypes of Murex echinatus Brocchi, 1814 are figured and commented. 


\begin{abstract}
RÉSUMÉ
Trois nouvelles espèces de Raphitoma Bellardi, 1847 (Mollusca, Gastropoda, Raphitomidae) de Croatie (nord-est de l'Adriatique).

Trois nouvelles espèces de néogastropodes de la famille des Raphitomidae Bellardi, 1875 sont décrites des côtes croates de l'Adriatique : Raphitoma petanii Prkić, Giannuzzi-Savelli \& Pusateri n. sp., R. pusaterii Prkić \& Giannuzzi-Savelli n. sp., et $R$. stanici Prkić, Giannuzzi-Savelli \& Pusateri n. sp. Ces nouvelles espèces sont différenciées dans un cadre de taxonomie intégrative par des caractères de la téléoconque et des données génétiques (séquences du COI). Elles appartiennent à un groupe d'espèces qui présentent des microgranules sur la surface externe de toutes les spirales de la téléoconque, et toutes trois ont une protoconque multispiralée, indiquant une phase larvaire planctotrophe. Raphitoma petanii Prkić, GiannuzziSavelli \& Pusateri n. sp. et $R$. stanici Prkić, Giannuzzi-Savelli \& Pusateri n. sp. sont essentiellement des espèces d'eaux peu profondes, tandis que $R$. pusaterii Prkić \& Giannuzzi-Savelli n. sp. n’a été collectée que sur des fonds plus profonds avec du corail rouge, Corallium rubrum (Linnaeus, 1758). Raphitoma petanii Prkić, Giannuzzi-Savelli \& Pusateri n. sp. et $R$. pusaterii Prkić \& Giannuzzi-Savelli n. sp. ne sont connues à ce jour que de Croatie. Les syntypes de Murex echinatus Brocchi, 1814 sont figurés et discutés.
\end{abstract}

mer Adriatique, espèces nouvelles.
MOTS CLÉS

\section{INTRODUCTION}

The available knowledge on the diversity of marine Mollusca in Croatia is still scarce. Despite the 7000-8000 species of marine organisms so far inventoried (Chemonics International Inc. 2000), little is still known about the malacofauna of this area. Historically, after the few important works on the Dalmatian malacofauna in the second half of nineteenth century (e.g.: Danilo \& Sandri 1855, 1856; Brusina 1865, 1866, $1872-$ 1908; Klećak 1873), there have been very few additional studies published. Particularly rare are the works with lists of gastropod species. However, a still unpublished preliminary checklist of Croatian Mollusca (J. Prkić, pers. comm.), contains more than 1200 species, among which more than 900 are gastropods, including many probably undescribed taxa.

Raphitomidae Bellardi, 1875, probably the most diverse family of Conoidea J. Fleming, 1882 (Kantor \& Taylor 2002; Bouchet et al. 2011) are represented in the Mediterranean by c. 50 species. The limits of the type genus Raphitoma Bellardi, 1847 in the Northeastern Atlantic and Mediterranean have been recently redefined (Fassio et al. 2019) to comprise the fossil type species $R$. histrix Bellardi, 1847 and its extant descendant $R$. pseudohystrix (Sykes, 1906), the spiny species such as $R$. cordieri (Payraudeau, 1826) and R. horrida (Monterosato, 1884 ) and the species that have been sometimes grouped into the (sub)genus Philbertia Monterosato, 1884. Members of this family from Croatia were mentioned in several papers by various authors but their number was always estimated to be surprisingly low; even in the Brusina collection, stored at Hrvatski Prirodoslovni Muzej (HPM) in Zagreb, there are only eight species of Raphitomidae (Ilijanić \& Stošić 1972). The following nominal taxa have been reported from Croatia: Clathromangelia granum (Philippi, 1844), Raphitoma aequalis (Jeffreys, 1867), R. atropurpurea (Locard \& Caziot, 1899), R. bicolor (Risso, 1826), R. cf. brunneofasciata Pusateri, Giannuzzi Savelli \& Oliverio, 2012, R. concinna (Scacchi, 1836), R. cordieri, R. echinata (Brocchi, 1814), R. ephesina Pusateri \& Giannuzzi Savelli \& Sthalschmidt, 2017, R. histrix, R. la- viae (Philippi, 1844), R. lineolata (B.D,D., 1883), R. locardi Pusateri, Giannuzzi Savelli \& Oliverio, 2013, R. papillosa (Pallary, 1904), R. philberti (Michaud, 1829), R. purpurea (Montagu, 1803), $R$. reticulata (Renier, 1804), $R$. smriglioi Pusateri \& Giannuzzi Savelli, 2013, Teretia teres (Reeve, 1844) (e.g. Stossich 1880; Coen \& Vatova 1932; Vio \& Min 1999; Zavodnik \& Kovačić 2000; Romani et al. 2018). According to our data some of these records need to be checked, but over 35 named and unnamed raphitomid morphospecies actually occur in Croatia (J. Prkić, pers. comm.).

In a work aimed at detecting poecilogony in the genus Raphitoma, Russini et al. (2020) used an integrative approach to species delimitation, where species are considered as hypotheses to be subsequently tested by independent approaches (Puillandre et al. 2009): in their work, Russini et al. (2020) yielded 10 robust final species hypotheses: $R$. pseudohystrix, $R$. purpurea, $R$. maculosa Høisaeter, 2016, R. cordieri, $R$. horrida, R. densa (Monterosato, 1884), R. laviae, R. philberti, and two unnamed Croatian species. Based on these and additional molecular analyses, and on morphological observations on a third unnamed morphospecies, we describe here the three Croatian entities as new species.

\section{MATERIAL AND METHODS}

Specimens studied in this work are housed in private and public collections. Most of the specimens were found alive, under small and medium-sized stones at 0-20 m depth, where they were manually collected during snorkelling or scuba diving. Empty shells were sorted out of bioclastic sediment samples collected manually at 1-30 m depth, or amidst the residuals of material collected during red coral fishing at $60-100 \mathrm{~m}$ depth by scuba divers. We have used a standardised format for the citation of specimen data in Type Material and Other material examined sections, as described by Chester $e$ et al. (2019).

SEM images were taken by Nanovision srl., Brugherio (with a Hitachi TM4000Plus: Figs 6A-C; 9A-E; 11A-E), by Andrea 


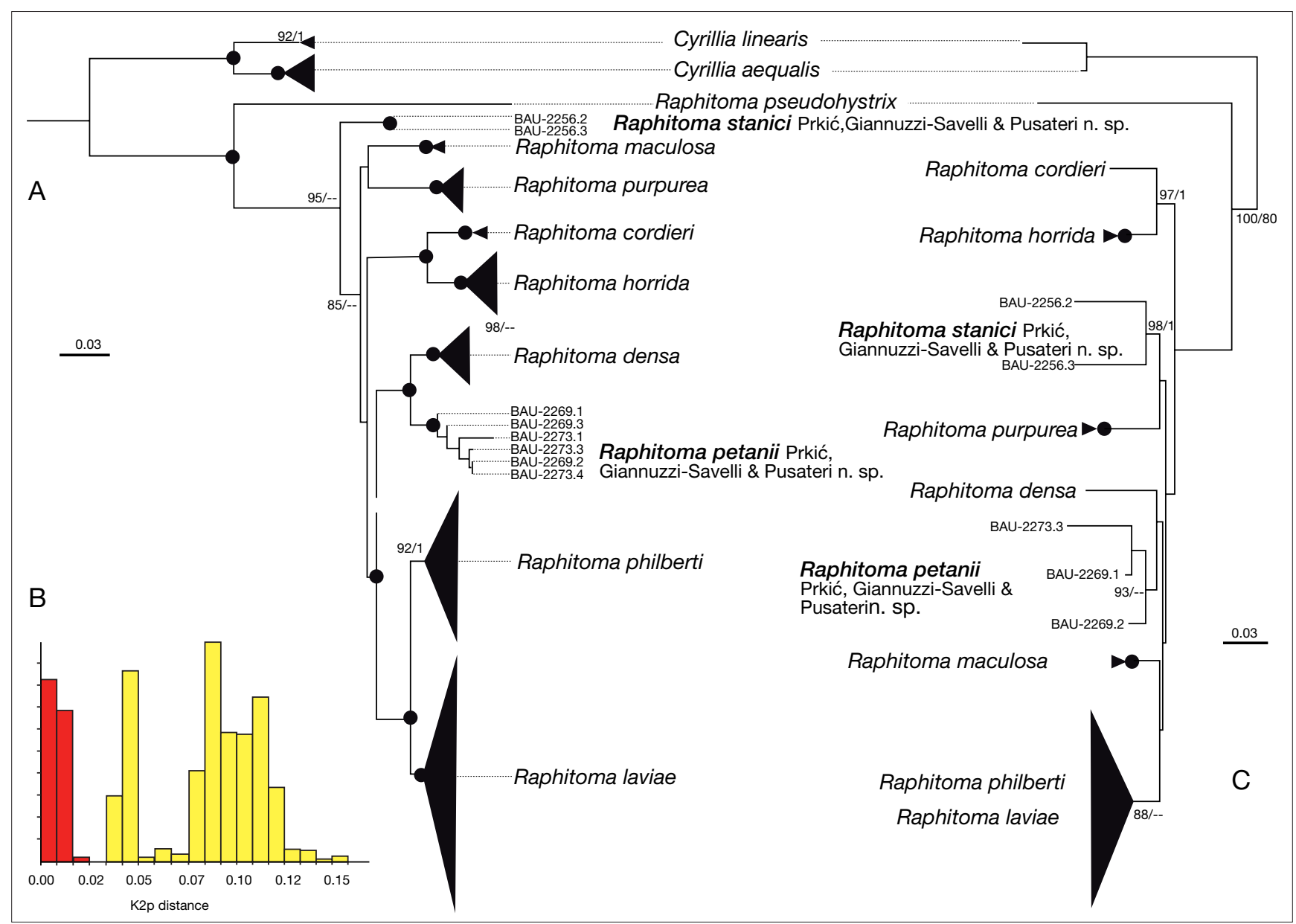

FIG. 1. - Phylogenetic relationships (maximum likelihood topologies) among species of the genus Raphitoma (see Russini et al. 2020 for further details). Numbers at nodes are bootstrap supports after 1000 pseudoreplicates, and posterior probabilities after a Bayesian analysis on the same dataset; only values higher than $75 \%$ bootstrap support and $95 \%$ posterior probability are reported; black dots indicate nodes supported by $100 \%$ bootstrap and 1.0 posterior probability. A, ML analysis on the combined dataset $(\mathrm{COI}+16 \mathrm{~S}+12 \mathrm{~S}+\mathrm{ITS} 2)$; $\mathbf{B}$, the histogram portraying the distribution of the pairwise genetic distances (K2p) among the COI sequences (red bars on the left are intraspecific comparisons, yellow bars on the right are interspecific comparisons); C, ML analysis on the ITS2 alignment.

Di Giulio at the "LIME" (Interdepartmental Laboratory of Electron Microscopy - Roma Tre University) (Fig. 6D, E) and by Martina Paolini at Museo di Scienze Naturali di Milano (Fig. 15A-E). Light photographs were taken by Stefano Bartolini (Firenze) using a Canon EOS 400D digital photocamera, with standard $50 \mathrm{~mm}+$ adapted objectives (25 and $12.5 \mathrm{~mm}$ ) for 16 and $8 \mathrm{~mm}$ vintage cine camera (Figs 3A-G; 4B, H; 8A, B, E, F; 10A-F); by Jakov Prkić using a Canon PowerShot A480 digital camera (Figs 4F, G; 5A, B; 13E; 17); by Alen Petani using an Olympus Tough TG-5 digital camera (Figs 4C, D; 5C-H) and a Canon PowerShot A480 digital camera (Figs 7A-C; 12A, B); by Pero Ugarković using a Nikon D90 digital camera with objective Nikon AF-s DX Micro Nikkor $40 \mathrm{~mm}$ f/2.8G and ring flash Nikon Speedlight SB-21 (Figs 4A, E; 8C, D; 16A, D).

The number of protoconch whorls (Fig. 2) has been counted according to the method of Verduin (1976). Protoconch and teleoconch morphometrics are based on Croatian samples of 26 sh of $R$. petanii Prkić, Giannuzzi-Savelli \& Pusateri n. sp., 10 sh of $R$. pusaterii Prkić \& Giannuzzi-Savelli n. sp., 26 sh of R. stanici Prkić, Giannuzzi-Savelli \& Pusateri n. sp., and 18 sh of $R$. densa; additionally, data on $R$. contigua (Monterosato, 1884 ) and $R$. corbis (Potiez \& Michaud, 1838), are derived from Giannuzzi-Savelli et al. (2018b) and Pusateri et al. (2018).

\section{SPECIES DELIMITATION}

Sequences in the present work have been used by Russini et al. (2020): we refer to that work for details on the species delimitation analyses. In summary, a series of morphologically based Preliminary Species Hypotheses (PSH) were preliminarily defined by using shell characters to identify putative species, based on the most recent taxonomy of the group (Pusateri et al. 2012, 2013, 2016, 2018; Giannuzzi-Savelli et al. 2017, 2018a, b). The PSH were then tested by a multi-step molecular approach: first step, the distance-based Automatic Barcode Gap Discovery (ABGD, available at http://wwwabi.snv.jussieu.fr/ public/abgd/), was used to group specimens after an analysis of the distribution of pairwise distances in a COI alignments. ABGD employs an automatic procedure to sort the sequences into hypothetical species based on the barcode gap, which can be observed whenever the divergence among organisms belonging to the same species is smaller than divergence among organ- 


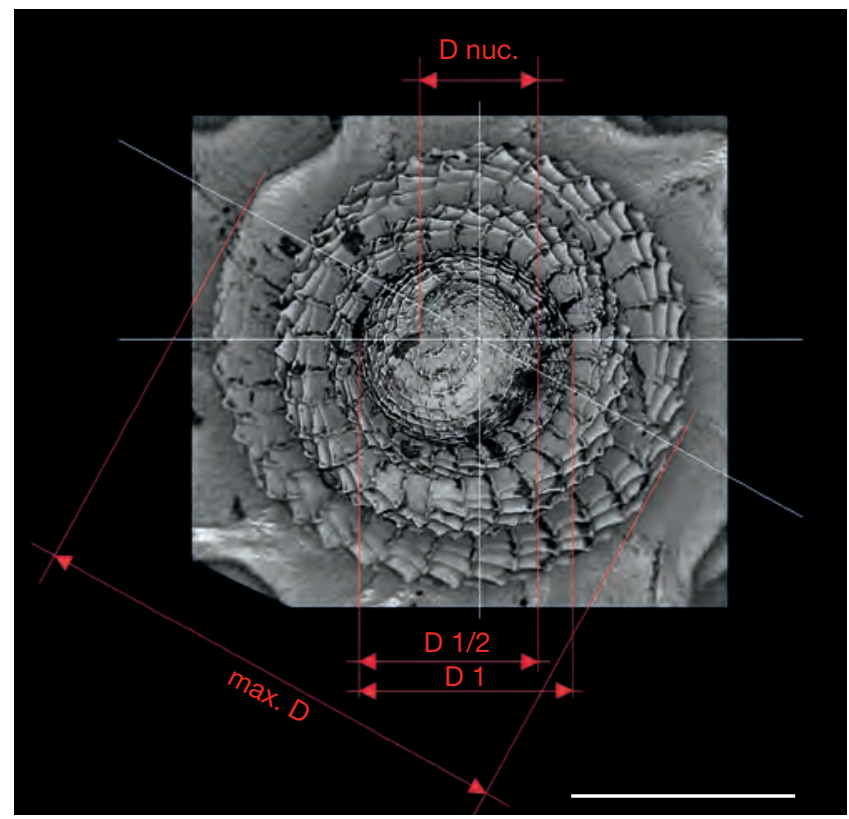

FIG. 2. - Measurements taken on protoconch of Raphitoma pusaterii Prkić \& Giannuzzi-Savelli n. sp. Diameter of nucleus (D nuc. $=105 \mu \mathrm{m}$ ), diameter of first half-whorl $(\mathbf{D} 1 / 2=159 \mu \mathrm{m})$, diameter of first whorl $(\mathbf{D} 1=190 \mu \mathrm{m})$, maximum diameter (Max. $\mathbf{D}=440 \mu \mathrm{m})$, number of whorls $(\mathbf{P W}=3.6)$, number of whorls of protoconch 1 (PW 1 = 1.1). Scale bar: $200 \mu \mathrm{m}$.

isms from different species; second step reiterated on the ITS2 alignment; third step, the species hypotheses retained after the ABGD analyses were eventually tested for their reciprocal monophyly by performing Maximum Likelihood (ML) and Bayesian inference (BI) phylogenetic analyses on single-gene alignments and on a concatenated dataset (COI + 16S + 12S + ITS2), using Cyrillia linearis (Montagu, 1803) and Cyrillia aequalis (Jeffreys, 1867) as outgroup for the genus Raphitoma (Fassio et al. 2019); and fourth step, diagnostic nucleotides were identified on the COI and the ITS2 alignments by the r-package spider (Brown et al. 2012). Analyses for steps 1 and 3 were performed in the work by Russini et al. (2020); analyses for the steps 2 and 4 we performed for this work.

Nodes with Bootstraps support (BS) of 70-90\% and Posterior Probabilities (PP) of 0.90-0.95 have been considered as moderately supported; those with $\mathrm{BS}>90 \%$ and $\mathrm{PP}>$ 0.95 have been consider as highly supported.

\section{ABBREVIATIONS}

Institutions

HPM Hrvatski Prirodoslovni Muzej, Zagreb;

MCZR Museo Civico di Zoologia, Roma;

MCSNM Museo Civico di Scienze Naturali, Milano;

MNHN Muséum national d'Histoire naturelle, Paris;

MZB Museo Zoologia Università Bologna.

\section{Private collections}

coll. LET Neven Lete collection;

coll. PET Alen Petani collection;

coll. PRK Jakov Prkić collection;

coll. PUS Francesco Pusateri collection;

coll. RGS Riccardo Giannuzzi-Savelli collection;

coll. STA Rino Stanić collection.

$\begin{array}{ll}\text { Morphometrics } \\ \text { D } & \text { diameter; } \\ \text { H } & \text { height; } \\ \text { h/d } & \text { height/diameter rate; } \\ \text { PW } & \text { protoconch whorls; } \\ \text { SD } & \text { Standard Deviation; } \\ \text { TW } & \text { teleoconch whorls. }\end{array}$

\section{Observed material \\ lv live collected specimen(s); \\ sh empty shell(s).}

\section{RESULTS}

The recursive ABGD analysis on the ITS2 alignment identified the same two putative unnamed Croatian morphospecies yielded by Russini et al. (2020). The K2p genetic divergence at the barcode fragment (COI) ranged from $0.2 \%$ to $0.9 \%$ within species, and from $4.3 \%$ to $18.9 \%$ between species. All species hypotheses defined based on the ABGD analyses, resulted as monophyletic when represented by more than one specimen, after multilocus phylogenetic analyses (Maximum Likelihood and Bayesian Inference: Fig. 1), including the two putatively undescribed ones.

Diagnostic nucleotides have been thus identified at both COI and ITS2. They are summarized in Table 1, and are reported in the descriptions of the new taxa.

A thorough scrutiny of the known literature on northeastern Atlantic fossil and extant raphitomid species did not yield any available name for these undescribed species. Therefore, they are herein described as new along with a third one, for which we did not find specimens suitable for DNA analysis, but clearly distinct morphologically from any other species of Raphitoma.

\section{SYSTEMATICS}

Citation of unpublished names is not intended for taxonomic purposes.

Family RAPHITOMIDAE Bellardi, 1875

Genus Raphitoma Bellardi, 1847

Raphitoma Bellardi, 1847: 84.

Homotoma Bellardi, 1875: 22, non Homotoma Guérin-Méneville, 1844 (type species Murex textile Brocchi, 1814 by subsequent designation [Fischer 1883]).

Cordieria Monterosato, 1884: 131, non Cordieria Rouault, 1848 (type species Murex reticulatus Brocchi, 1814, by subsequent designation [Crosse 1885]).

Philbertia Monterosato, 1884: 132 (type species Pleurotoma philberti Michaud, 1829 by subsequent designation [Crosse 1885]).

Peratoma Harris \& Burrows, 1891: 113 (nomen novum pro Homotoma Bellardi, 1875, non Homotoma Guérin-Méneville, 1844).

TyPE SPECIES. - Pleurotoma hystrix Cristofori \& Jan, 1832 (nomen nudum, made available by Bellardi 1847 as "Pleurotoma histrix Jan.") by subsequent designation (Monterosato 1872: 54). 


\author{
Raphitoma petanii \\ Prkić, Giannuzzi-Savelli \& Pusateri n. sp. \\ (Figs 3A-G; 4A-H; 6A-C; 7A, B)
}

urn:Isid:zoobank.org:act:779382FF-84AC-451D-932D-C27E6BAE6AD3

Raphitoma sp. B - Russini et al. 2020: 301.

Type MATERIAL. - Holotype. Croatia • lv; MNHN-IM-2000-34887 (height $10.65 \mathrm{~mm}$, width $3.93 \mathrm{~mm}$ ); Stari Trogir Bay; 4329'21"N, 1602'37'E; 1-4 m depth.

Paratypes. Croatia • $1 \mathrm{lv}$; MNHN-IM-2000-34888; same locality data as holotype $\bullet 1 \mathrm{lv}$; MCZR-M-TYPE-00118; same locality data as holotype $\bullet 1 \mathrm{lv}$; HPM 11500 ; same locality data as holotype $\bullet 1 \mathrm{lv}$; MZB 60233; same locality data as holotype 12 lv; coll. PRK; same locality data as holotype $\bullet 2$ lv; coll. RGS-120245, coll. RGS-120246; same locality data as holotype $\bullet 1 \mathrm{lv}$; coll. PUS-2798; same locality data as holotype $1 \mathrm{lv}$; coll. PET; same locality data as holotype - 6 lv; BAU-2269.1-3, BAU-2273.1, BAU-2273.3, BAU-2273.4; Sukošan; 4401'30”N, $15^{\circ} 20^{\prime} 50^{\prime \prime E}$; 2-6 m depth.

Type locality. — Croatia, Stari Trogir Bay (Sevid); 4329’21”N, $16^{\circ} 02^{\prime} 37^{\prime \prime E}$; $1-4 \mathrm{~m}$ depth.

OTHer MATERIAL EXAMINED. — Croatia • 1 lv; coll. PET; Vrsi, Jasenovo 1 lv; coll. PET; Zaton, Bilotinjak • 6 lv; coll. PET; Sukošan, Mala Makarska • 1 lv; coll. PET; Sukošan, Tustica $\bullet 1$ lv; coll. PET; Turanj • 9 lv; coll. PRK; Biograd, Bošana • 58 lv; coll. PET; Biograd, Bošana • 1 lv; coll. PET; Pakoštane $\bullet 3$ lv, 3 sh; coll. PRK; Murter Island, Kosirina Bay $\bullet 1$ lv; coll. PET; Murter Island, Kosirina Bay - 7 lv, 2 sh; coll. PRK; Sevid, Stari Trogir Bay • 24 lv; coll. PET; Sevid, Stari Trogir Bay $\bullet 5$ lv; coll. RGS; Sevid, Stari Trogir Bay $\bullet 5$ lv; coll. STA; Brač Island, Milna • 9 lv; coll. STA; Brač Island, Maslinova Bay 1 lv; coll. PRK; Duće Vavlje $\bullet 3$ sh; coll. PRK; Mljet Island.

DiSTRIBUTION. - This species is so far known only from Croatia, based on the material examined, with samples collected in 0-19 m depth, but we do not exclude the possibility that it occurs also in some other Mediterranean areas.

Etymology. - After Alen Petani, for his great contribution to the study of the Croatian raphitomids and to the present paper.

HABITAT. - This species has been collected on rocky bottoms with plenty of small and medium-sized stones, on the underside of which the specimens are found at daytime. This is a shallow-water species, more than 150 live specimens having been found at $0.5-4 \mathrm{~m}$ depth, and only a few on slightly deeper bottoms (max $19 \mathrm{~m}$, at Brač Island: R. Stanić, pers. comm.). R. petanii Prkić, GiannuzziSavelli \& Pusateri n. sp. often lives in sympatry/syntopy with other raphitomids (Cyrillia linearis, Leufroyia concinna (Scacchi, 1836), L. leufroyi (Michaud, 1828), Raphitoma contigua, $R$. cordieri, $R$. densa, $R$. echinata AA. - morphotype 2 [see below], $R$. laviae, $R$. stanici Prkić, Giannuzzi-Savelli \& Pusateri n. sp., etc.), sometimes with specimens of 5-6 different species occurring under the same stone.

DESCRIPTION [in square brackets the data of the holotype] Shell

Solid, fusiform-acute, of medium size for the genus. Height: 8.2-12.4 mm [10.65]; width: 3.06-4.94 mm [3.93]; h/d: $2.38-2.84[2.71]$

\section{Protoconch}

Multispiral, of 2.6-3.25 [2.9] convex whorls. Height: $546 \mu \mathrm{m}$, maximum diameter: $447 \mu \mathrm{m}$ (in specimen with $\mathrm{PW}=3.1$, Fig. 6A-C). Protoconch I of 1 whorl, $196 \mu \mathrm{m}$ in diameter, covered by dense cancellate sculpture; protoconch II with axial threads below the suture and less dense and diagonally cancellate sculpture on the rest of whorl. A strong keel at the end of last whorl covered with microgranules, denser above the keel. Protoconch-teleoconch boundary of flexuose, opisthocline growth lines. Colour brownish with white nucleus.

\section{Teleoconch}

Of 6.1-7.25 [7] slightly convex, not stepped whorls, suture incised, sculpture prominent, whole surface covered with dense microgranules. Axial sculpture of 18-27 [24] equidistant, narrow, orthocline or slightly opisthocline ribs, narrower than interspaces, broader than spiral cords. Spiral sculpture of 20-26 [23] spiral cords on the last whorl, of which 6-8 [7] primary cords above the aperture, and two [2] secondary cordlets on the subsutural ramp. Siphonal fasciole with 9-12 [10] strong nodulose cords. Cancellation usually subquadrate, sometimes slightly rectangular, with not very elongate tubercles at intersections; tubercles on first 3 adapical primary cords more or less spinulose, often also on secondary cordlets. Subsutural ramp narrow, inclined. Columella simple, straight and inclined to the right anteriorly, gently angled posteriorly. Siphonal canal of medium length, widely open at the end; posterior canal broad. Outer lip thick, with 9-14 [11] strong inner plicate denticles.

\section{Colour}

Brownish or chestnut brown background, often very dark, sometimes with brown-yellowish or brown-greyish hue, interspaces always darker. White, whitish or ash grey blotches and spots of variable size, occasionally absent or very small, or covering most of surface.

\section{Soft parts}

Foot long and broad, deeply bilobed anteriorly and with recurved anterolateral corners, narrowly tapering posteriorly. Head small with a pair of long cylindrical tentacles, black eyes on bulges about halfway along their length, the distal part slightly longer and much narrower than the basal. Proboscis rather long and much narrower at the base than at the tip. Colour translucent white or yellowish-white on background, with minute white speckles covering the whole body, including entire length of tentacles, scattered or absent on the sole. Black to dark-grey pigments on head around the base of tentacles and extending on right side down to about halfway to edge of foot. Siphon tip with dense white speckles and a translucent white or yellowish ring, rest of siphon dark grey or grey-brownish with few and scattered white specks. Proboscis pure white and without specks.

\section{Diagnostic nucleotides}

\section{7, 70, 112, 250, 533, 539 (COI), and 297 (ITS2).}

\section{REMARKS}

The number of teleoconch whorls significantly varies in specimens of the same size, while specimens very different in size may have the same number of TW: for example, two specimens $10.28 \mathrm{~mm}$ and $8.35 \mathrm{~mm}$ long, respectively, both have the same number of whorls (6.25). 


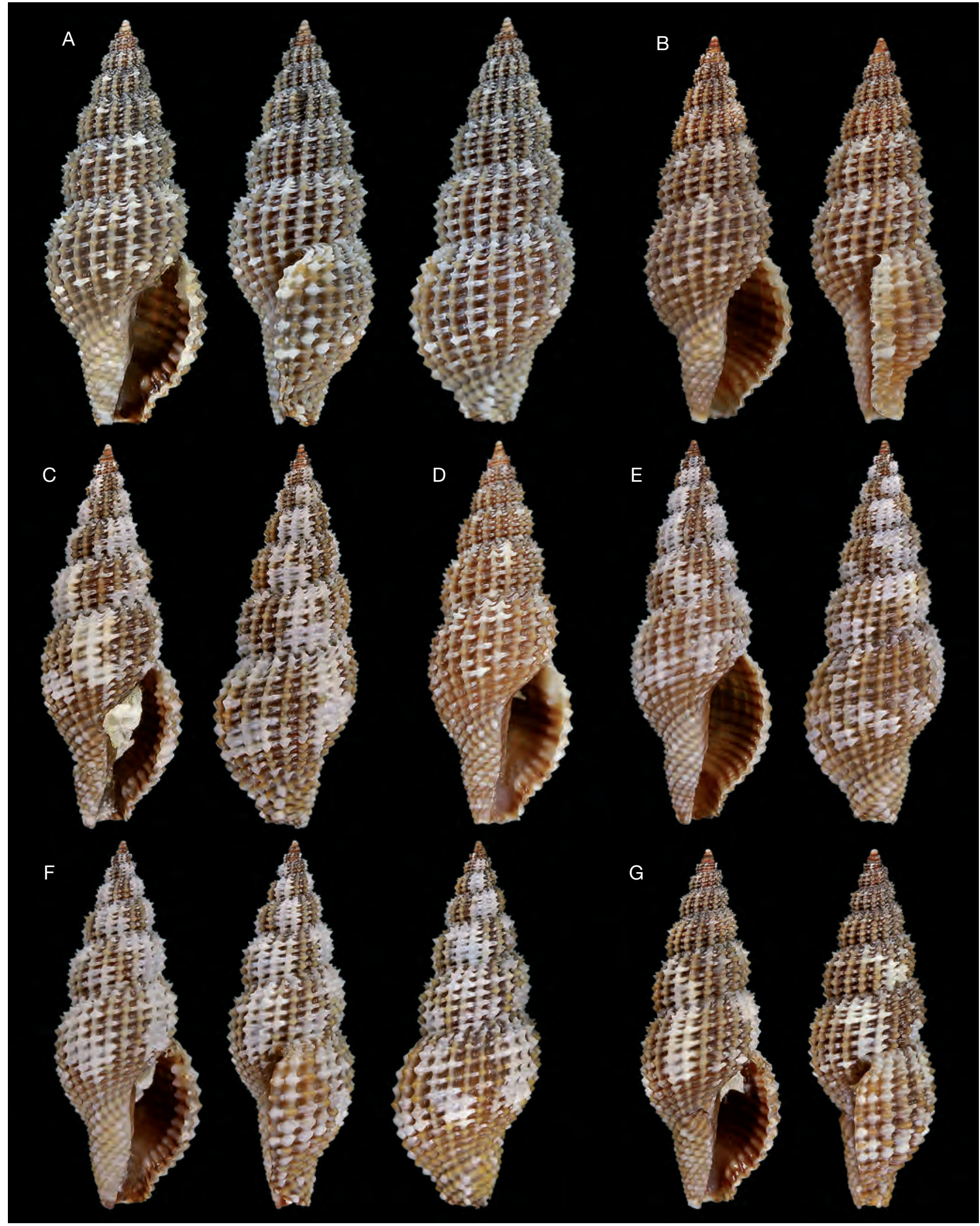

FIG. 3. - Raphitoma petanii Prkić, Giannuzzi-Savelli \& Pusateri n. sp., Stari Trogir. A, holotype, MNHN-IM-2000-34887, h = 10.65 mm; B, paratype, coll. RGS 120245, h = 9.6 mm; C, paratype, MCZR-M-TYPE-00118, h = 9.25 mm; D, paratype, MNHN-IM-2000-34888, h = 9.3 mm; E, paratype, coll. PUS 2798 , h = 9.7 mm; F, paratype, HPM 11500, h = $8.7 \mathrm{~mm}$; G, paratype, MZB 60233, h=8.2 $\mathrm{mm}$. 


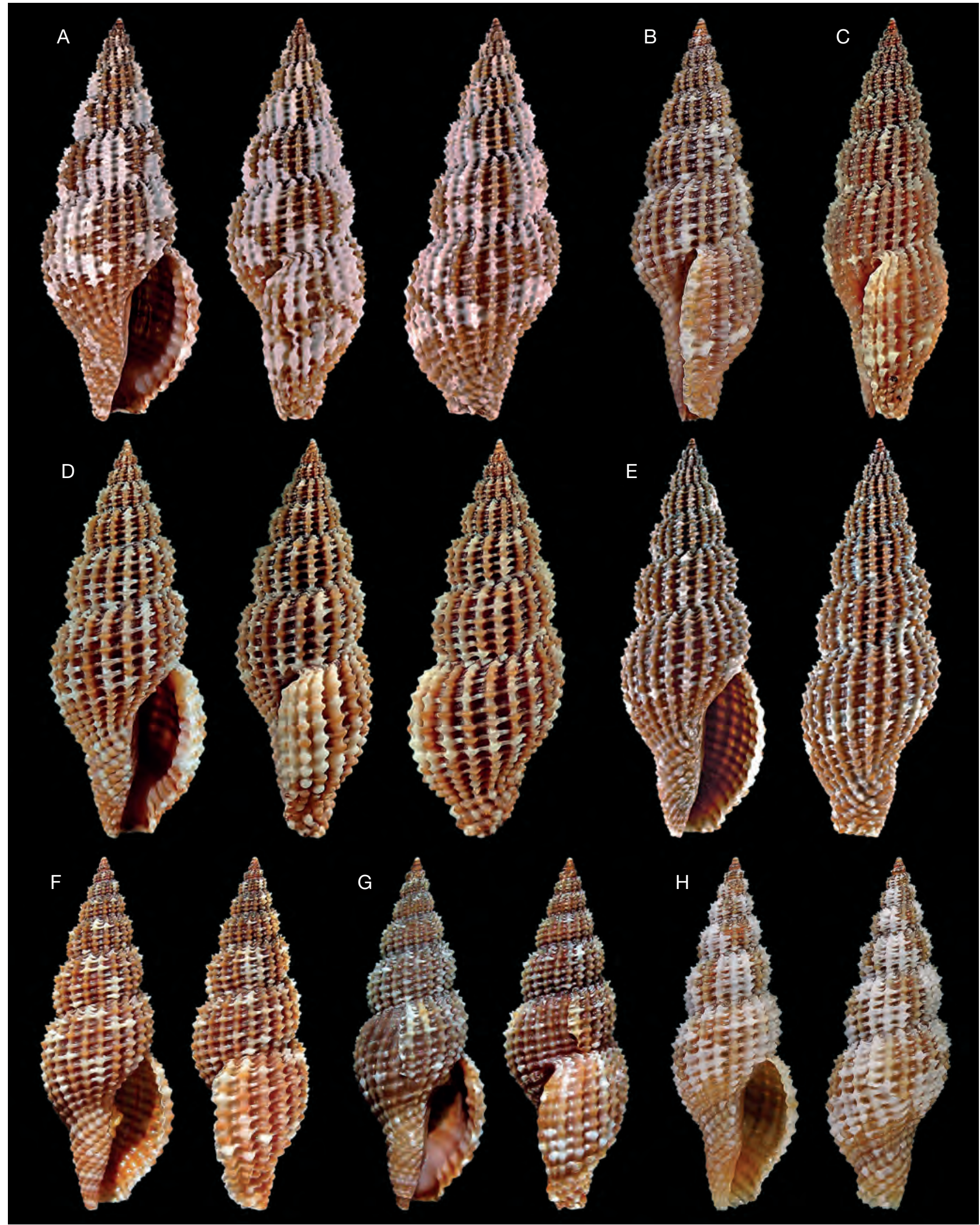

FIG. 4. - Raphitoma petanii Prkić, Giannuzzi-Savelli \& Pusateri n. sp.: A, Stari Trogir, paratype, coll. PRK, h=11.05 mm; B, Stari Trogir, paratype, coll. RGS 120246, $h=11.8 \mathrm{~mm}$; C, Stari Trogir, paratype coll. PET, $h=11.55 \mathrm{~mm}$; D, Sukošan, coll. PET, $\mathrm{h}=12.4 \mathrm{~mm}$; $\mathrm{E}$, Stari Trogir, paratype, coll. PRK, $\mathrm{h}=12.05 \mathrm{~mm}$; F, Biograd coll. PRK, $h=10.3 \mathrm{~mm}$; G, Murter Is., coll. PRK, $h=10.3 \mathrm{~mm} ; \mathbf{H}$, Stari Trogir, coll. RGS, $\mathrm{h}=9.1 \mathrm{~mm}$. 


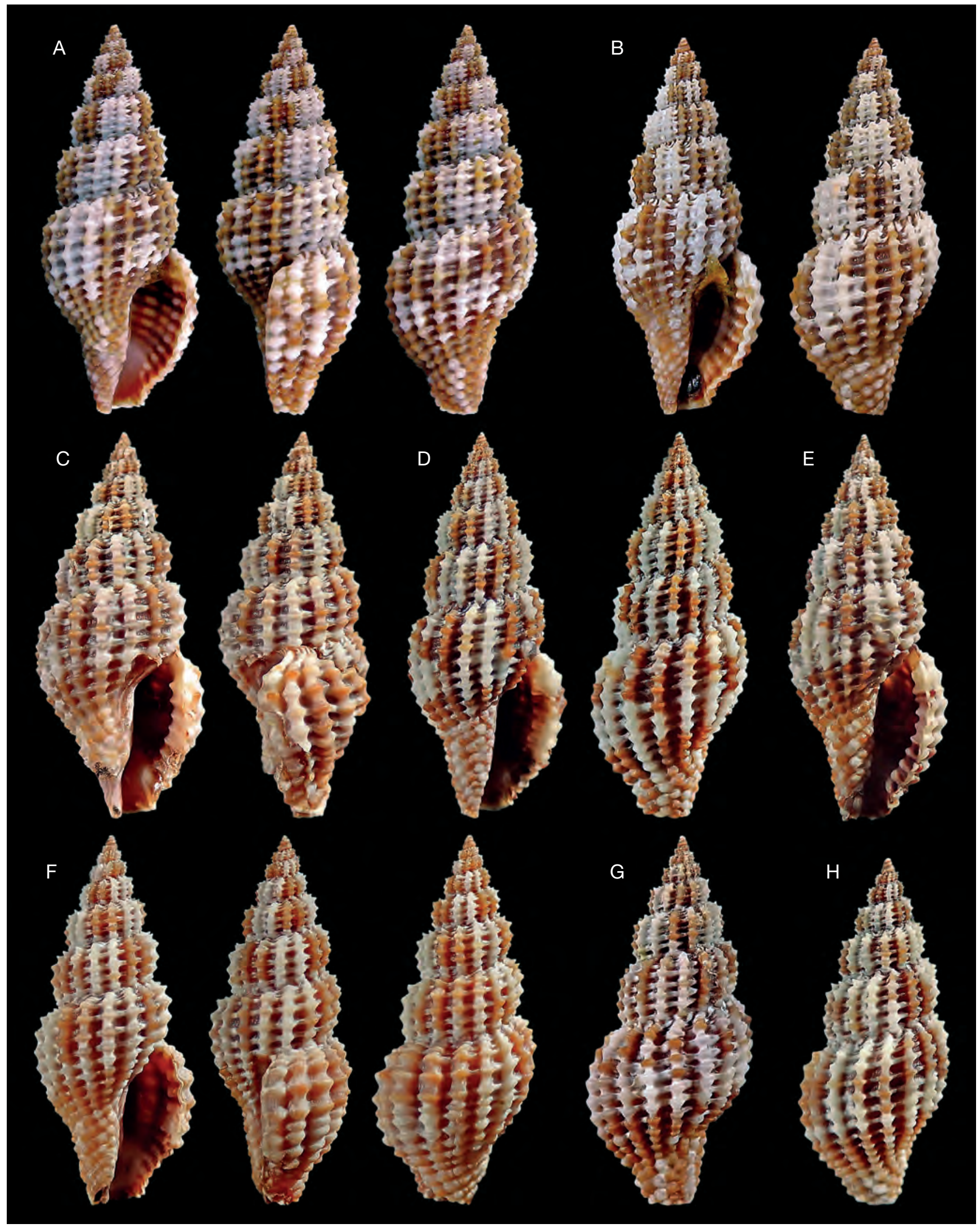

FIG. 5. - Raphitoma densa (Monterosato, 1884): A, Murter Is., coll. PRK, $h=11.3 \mathrm{~mm}$; B, Biograd, coll. PRK, $\mathrm{h}=10.2 \mathrm{~mm}$; C, Vrsi, coll. PET, $\mathrm{h}=11.55 \mathrm{~mm}$; D, Vir Is., coll. PET, $h=11.0$ mm; E, Murter Is., coll. PET, $h=11.6$ mm; F, Sukošan, coll. PET, $h=10.75$ mm; G, Vrsi, coll. PET, $h=10.0$ mm; H, Zaton, coll. PET, $h=8.8$ mm. 


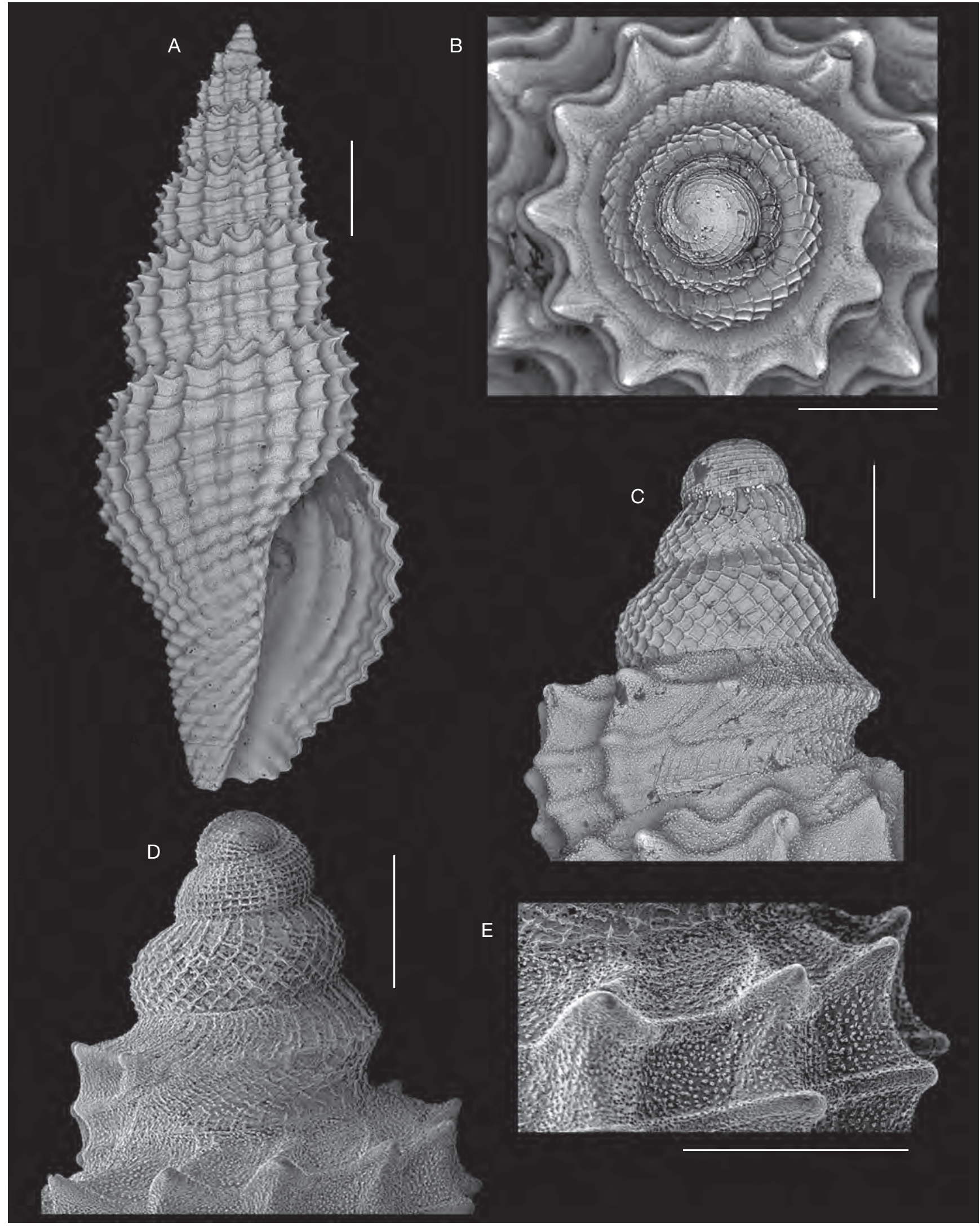

FIG. 6. - A-C, Raphitoma petanii Prkić, Giannuzzi-Savelli \& Pusateri n. sp., Stari Trogir, $\mathrm{h}=8.05 \mathrm{~mm}$, frontal view of shell (A), apical (B) and frontal (C) view of protoconch; D, E, Raphitoma densa (Monterosato, 1884), protoconch (D) and detail of microgranules at first teleoconch whorl (E). Scale bars: A, 1 mm; B-E, 200 um. 

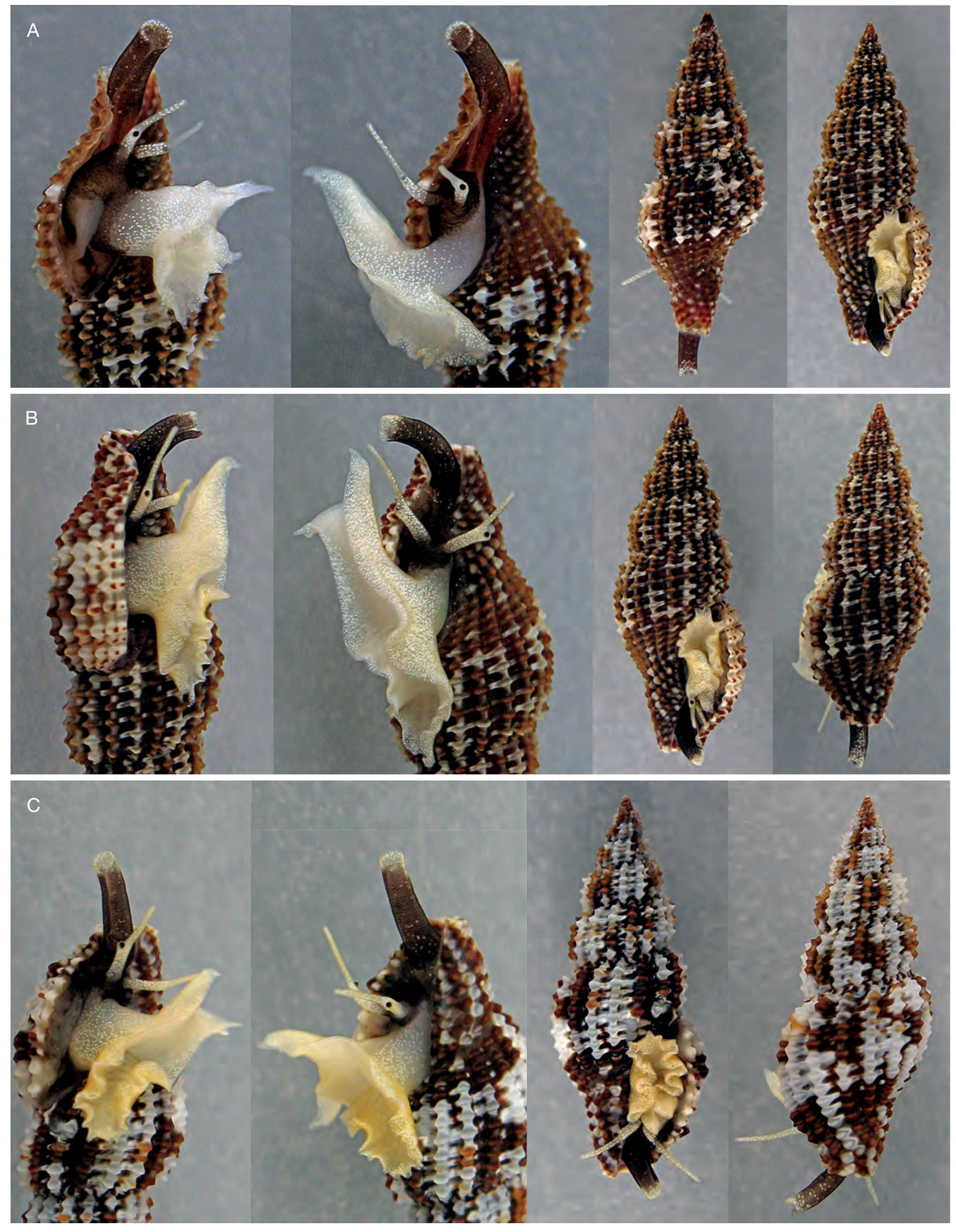

FlG. 7. - Photographs of living animals of Raphitoma petanii Prkić, Giannuzzi-Savelli \& Pusateri n. sp. (A, B) and Raphitoma densa (Monterosato, 1884) (C). A, Zaton, depth 1-2 m, h=7.85 mm; B, Sukošan, depth 0.5-1 m, h=12.45 mm; C, Vir Is., depth $1 \mathrm{~m}, \mathrm{~h}=11.1 \mathrm{~mm}$. Photos courtesy: A. Petani. 
Sometimes only one cordlet (adapical) may be present in the frontal view, but also in such cases the other one always gradually appears on the dorsal side of the last whorl, so at dorsal side both secondary cordlets are always present. These two secondary cordlets are often quite strong and with spinulose nodules, so they often look almost as primary cords.

This species can be confused only with Raphitoma densa (Monterosato, 1884) with which is often found living in sympatry. In Croatia, where $R$. petanii Prkić, GiannuzziSavelli \& Pusateri n. sp. is $c .5$ times more frequent than $R$. densa, the two species live in the same bathymetrical range and habitat, and no living or dead specimen has ever been found deeper than $19 \mathrm{~m}$. They share the presence of microgranules over the whole teleoconch, a similar protoconch, same maximum size of the shells, and same colour pattern of the soft parts. In our molecular phylogenetic analyses, $R$. petanii Prkić, Giannuzzi-Savelli \& Pusateri n. sp. and $R$. densa were sister species, reciprocally monophyletic and their genetic divergence (K2p) was $5-7 \%$, indisputably above the species level threshold.

$R$. densa is rather variable across its range in the Mediterranean (Giannuzzi-Savelli et al. 2018). However, Croatian specimens of $R$. densa have quite constant morphological characters which, in most cases (and with very few exceptions), allow to distinguish them relatively easily from shells of R. petanii Prkić, Giannuzzi-Savelli \& Pusateri n. sp. Therefore, we provide here diagnostic features between the two species as observed in the Croatian material.

\section{Protoconch}

The number of whorls varies similarly in both species, with $R$. densa showing only slightly fewer whorls (2.5-3.0, mean 2.79) than $R$. petanii Prkić, Giannuzzi-Savelli \& Pusateri n. sp., (2.6-3.25, mean 2.98). Also the exposed height of the protoconch seems to be slightly different, in a specimen of $R$. petanii Prkić, Giannuzzi-Savelli \& Pusateri n. sp. (Fig. 6AC) with 3.1 protoconch whorls the height is $546 \mu \mathrm{m}$, while in a specimen of $R$. densa (Fig. 6D, E) with 3.0 whorls the height is $508 \mu \mathrm{m}$.

\section{Axial ribs}

Axial ribs are much stronger and broader in $R$. densa than in $R$. petanii Prkić, Giannuzzi-Savelli \& Pusateri n. sp., and as a consequence also the tubercles are much more elongated in $R$. densa. Their number is also frequently (though not always) higher in $R$. petanii Prkić, Giannuzzi-Savelli \& Pusateri n. sp. (18-27, mean 22.55), than in $R$. densa (1619 , mean 17.46).

\section{Spiral cords}

The spiral sculpture above the aperture consists in both species of primary cords and two secondary cordlets on the shoulder between a narrow subsutural ramp and the first primary cord. In $R$. petanii Prkić, Giannuzzi-Savelli \& Pusateri n. sp. these two secondary cordlets are often quite strong and with spinulose nodules, so they often look al- most as primary cords, while in $R$. densa they are much weaker. In $R$. petanii Prkić, Giannuzzi-Savelli \& Pusateri n. sp. the spiral cords are only slightly weaker than the ribs, while in $R$. densa the ribs are much stronger than the cords. The spiral cords on the last whorl are often less numerous in $R$. densa (19-22, mean 20.64) than in $R$. petanii Prkić, Giannuzzi-Savelli \& Pusateri n. sp. (20-26, mean 23.5); above the aperture there are 5-6 (mean 5.85) primary cords in $R$. densa and 6-8 (mean 6.96) in $R$. petanii Prkić, Giannuzzi-Savelli \& Pusateri n. sp.

\section{Apertural denticles}

There are often slightly fewer denticles in $R$. densa (8-10, mean 9.5) than in $R$. petanii Prkić, Giannuzzi-Savelli \& Pusateri n. sp. (9-14, mean 11.32).

\section{Subsutural ramp}

In both species the subsutural ramp is narrow, but in $R$. petanii Prkić, Giannuzzi-Savelli \& Pusateri n. sp. the first secondary cordlet is very close to the suture and the ramp is quite inclined. In $R$. densa the first secondary cordlet is not so close to the suture and the ramp is much less inclined, resulting in more stepped whorls. White comma-shaped marks, which are very often present on the ramp of $R$. densa, are rarely observed in $R$. petanii Prkić, Giannuzzi-Savelli \& Pusateri n. sp.

\section{Tubercles}

They are more elongated and bluntly elevated in $R$. densa (only on the first 3 primary cords they can be moderately spinulose). In $R$. petanii Prkić, Giannuzzi-Savelli \& Pusateri n. sp. the tubercles on the first 3 primary cords and two secondary cordlets are more or less spinulose, often very spinulose.

\section{Colour}

The variation in colour of the teleoconch mostly overlaps in the two species, but only $R$. densa always have many large white blotches, while in $R$. petanii Prkić, GiannuzziSavelli \& Pusateri n. sp. these blotches can be present, but also completely absent (in the latter cases $R$. petanii Prkić, Giannuzzi-Savelli \& Pusateri n. sp. is very easily diagnosed).

\section{Slenderness $(h / d)$}

The shells of $R$. petanii Prkić, Giannuzzi-Savelli \& Pusateri n. sp. are generally more slender $(\mathrm{h} / \mathrm{d}=2.38-2.84$, mean 2.6$)$ than those of $R$. densa ( $\mathrm{h} / \mathrm{d}=2.24-2.46$, mean 2.37).

\section{Other differences}

Young and subadult shells are broader in $R$. densa, while at these growth stages $R$. petanii Prkić, Giannuzzi-Savelli \& Pusateri n. sp. already has a quite slender shell. General aspect of the outline of the shells is different, being more fusiform in $R$. petanii Prkić, Giannuzzi-Savelli \& Pusateri n. sp. because the whorls are not stepped. $R$. densa has a somewhat more robust aspect of the shell and more robust and less dense teleoconch sculpture. 


\author{
Raphitoma pusaterii \\ Prkić \& Giannuzzi-Savelli n. sp. \\ (Figs 8A-F; 9A-E)
}

urn:Isid:zoobank.org:act:CE75ED2B-10E0-4971-AAB0-7593588A637E

TYPE MATERIAL. - Holotype. Croatia • lv; MNHN-IM-2000-34889 (height $8.9 \mathrm{~mm}$, width $3.58 \mathrm{~mm}$ ); Mljet Island; 60-100 m depth. Paratypes. Croatia $\bullet 2$ sh; coll. PRK; same locality data as holotype - 2 sh; coll. RGS-120247, coll. RGS-120248; same locality data as holotype 4 sh; coll. LET; same locality data as holotype.

Type LOCAlity. - Croatia, Mljet Island; 60-100 m depth.

OTHER MATERial EXAMINED. - Croatia • 4 sh; coll. PRK; Mljet Island; same locality data as holotype $\bullet 2$ sh; coll. RGS; same locality data as holotype $\bullet 5 \mathrm{sh}$; coll. LET; same locality data as holotype - 2 sh; coll. PET; same locality data as holotype $\bullet 2$ sh; coll. STA; same locality data as holotype.

Distribution. - Only known from the material examined.

Etymology. - After Francesco Pusateri, for his great and wellknown contribution to the study of the Mediterranean raphitomids.

HАвітAт. - All available specimens (including the holotype and 2 paratypes that have dried soft parts inside the shell) were sorted out of dried residues obtained from scuba divers fishing red coral manually at 60-100 m depth. This material consisted of small pieces of fragmented rock, small quantity of mud, sponges, bryozoans, molluscs, brachiopods, echinoderms, etc. In Croatia the red coral community is particularly rich in molluscs, with more than 300 species so far inventoried (Prkić, unpublished data) at various depths and localities. Among them several species of Raphitomidae are common: Leufroyia concinna (Scacchi, 1836), L. erronea Monterosato, 1884, L. leufroyi (Michaud, 1828), L. villaria (Pusateri \& Giannuzzi-Savelli, 2008), Cyrillia linearis (Montagu, 1803) and Teretia teres (Reeve, 1844); others are uncommon or rare: Clathromangelia granum (Philippi, 1844), Pleurotomella gibbera Bouchet \& Warén, 1980, Cyrillia aequalis (Jeffreys, 1867); Raphitoma cf. atropurpurea (Locard \& Caziot, 1900), R. bicolor (Risso, 1826), R. echinata AA. - morphotype 1 [see below], $R$. cf. ephesina Pusateri, Giannuzzi-Savelli \& Stahlschmidt, 2017, R. farolita F. Nordsieck, 1977, R. cf. laviae (Philippi, 1844), $R$. lineolata (Bucquoy, Dautzenberg \& Dollfus, 1883), R. melitis Kontadakis \& Mbazios, 2019, R. pseudohystrix (Sykes, 1906), R. pusaterii Prkić \& Giannuzzi-Savelli n. sp., $R$. cf. spadiana Pusateri \& Giannuzzi-Savelli, 2012, and other still unidentified species.

DESCRIPTION [in square brackets the data of the holotype] Shell

Solid and fusiform-acute, of small size for the genus. Height: 6.8-9.2 mm [8.75]; width: 3.0-3.8 mm [3.57]; h/d: $2.27-$ $2.54[2.45]$.

\section{Protoconch}

Multispiral of 3.1-3.3 [3.1] convex whorls, occasionally up to 3.6 whorls (Figs 2; 9B). Protoconch I of 1.1 whorls $190 \mu \mathrm{m}$ in diameter, covered by dense cancellate sculpture; protoconch II with axial threads below the suture and less dense and diagonally cancellated sculpture on the rest of whorls. A short median strong keel at the end of last whorl, with minute spiral cordlets in between axial threads above keel. Protoconch-teleoconch boundary of strongly flexuose and opisthocline growth lines. Colour brownish with whitish nucleus, occasionally entirely whitish.

\section{Teleoconch}

Of 5.2-6.15 [6.05] slightly convex, stepped whorls, mean 5.7, suture incised, sculpture prominent, whole surface covered with dense microgranules. Axial sculpture of 17-21 [21] orthocline or slightly prosocline (occasionally slightly opisthocline), equidistant ribs, more evident than spiral cords, narrower than interspaces. Spiral sculpture of 21-23 [23] spiral cords on the last whorl, of which 7-8 [8] primary cords, occasionally 6, above the aperture and 2 [2] weak secondary cordlets on the subsutural ramp. Siphonal fasciole with 8-10 [10] strong nodulose cords. Cancellation rectangular, with strong and elongate tubercles at intersections; tubercles on first two primary cords and lower secondary cordlet slightly spinulose. Subsutural ramp very narrow, sometimes with short comma-shaped whitish spots. Columella simple, straight and inclined to the right anteriorly, gently angled posteriorly. Siphonal canal short and widely open at the end; posterior channel wide. Outer lip with 11 [11] occasionally 10 strong inner plicate denticles.

\section{Background colour}

Light orange-brownish, sometimes with a yellowish hue, lower part of last whorl occasionally slightly darker. Blotches and spots of variable size and number, white or just slightly lighter than the background colour. Interspaces between tubercles on ribs and cords frequently whitish or just lighter than the tubercles. One or two peripheral cords and some of axial ribs partially (or occasionally entirely) lighter or whitish.

\section{Soft parts}

Unknown.

\section{REMARKS}

The height and maximum diameter of protoconch depend on the number of whorls; in the photographed specimen (Fig. 9A-E) with $\mathrm{PW}=3.6$ these two features are: $\mathrm{H}=646 \mu \mathrm{m}$ and max. $\mathrm{D}=440 \mu \mathrm{m}$. All the specimens mentioned in the "Other material examined" paragraph consisted of juvenile or subadult shells.

R. pusaterii Prkić \& Giannuzzi-Savelli n. sp. may be easily confused with Raphitoma corbis (Potiez \& Michaud, 1838) by their similar colour, sculpture and profile of the shell. However, their protoconchs differ in the number of whorls (3.1-3.6 vs 2.4 in $R$. corbis), and as a consequence the protoconch of $R$. corbis also has smaller height and diameter. Teleoconch characters are mostly similar, but $R$. corbis does not have the microgranules. Also, the size of the shells seems to be different, the maximum registered height for fully adult R. pusaterii Prkić \& Giannuzzi-Savelli n. sp. is $9.2 \mathrm{~mm}$ (mean 7.88 ) vs $12.2 \mathrm{~mm}$ (mean 9.75 ) for $R$. corbis.

$R$. contigua (Monterosato, 1884) also shows some similarities with $R$. pusaterii Prkić \& Giannuzzi-Savelli n. sp., but they differ in the number of protoconch whorls (2.7 in $R$. contigua vs 3.1-3.6 in $R$. pusaterii Prkić \& GiannuzziSavelli n. sp.), max. size of the shell (16 mm in $R$. contigua vs $9.2 \mathrm{~mm}$ in $R$. pusaterii Prkić \& Giannuzzi-Savelli n. sp.), absence of microgranules and more glossy surface of the 



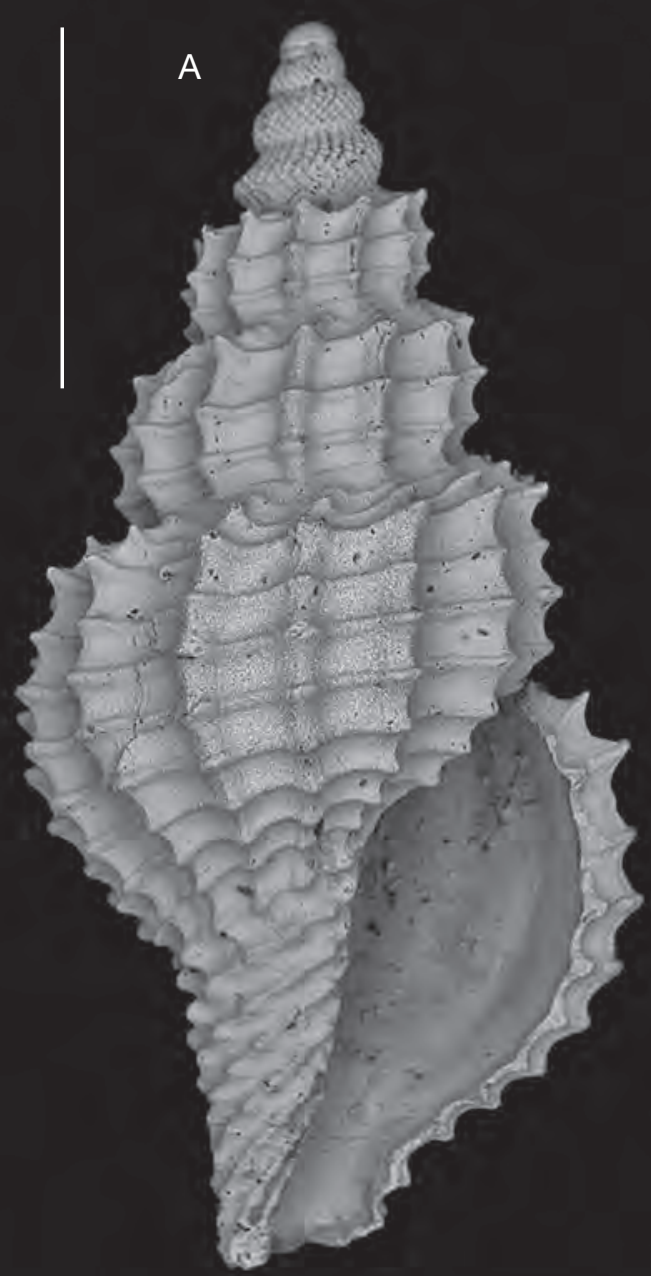

B
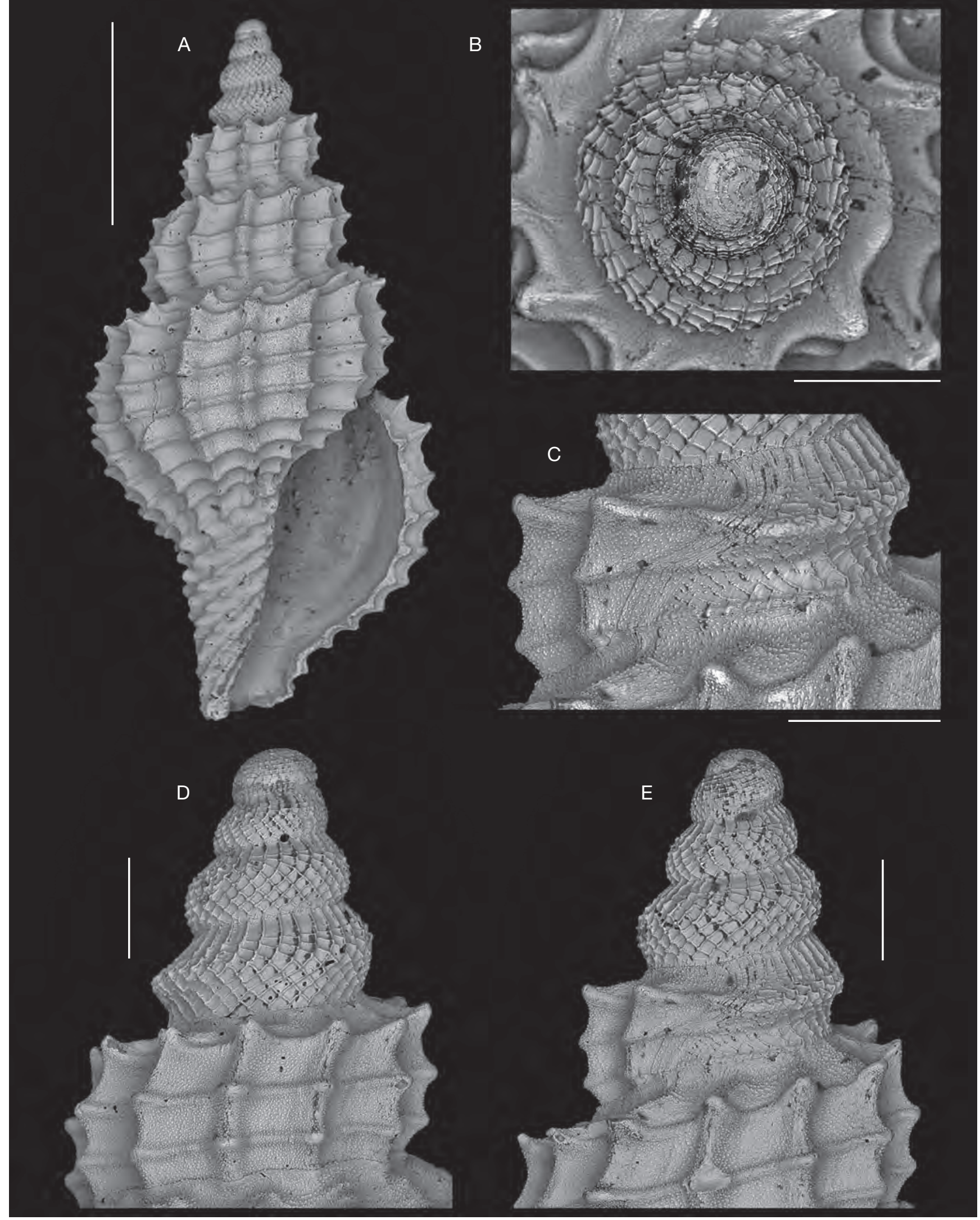

FIG. 9. - Raphitoma pusaterii Prkić \& Giannuzzi-Savelli n. sp., Mljet Island (coll. RGS, $h=3.46 \mathrm{~mm}$ ): frontal view of shell (A); apical (B), frontal (D) and dorsal (E) view of protoconch; detail of microgranules and transition from protoconch to teleoconch (C). Scale bars: A, $1 \mathrm{~mm} ; \mathrm{B}-\mathrm{E}, 200 \mu \mathrm{m}$. 
teleoconch in $R$. contigua, colour of the shell (light to dark tawny with dark interspaces between the cords in $R$. contigua vs light orange brownish or yellowish in $R$. pusaterii Prkić \& Giannuzzi-Savelli n. sp.).

\section{Raphitoma stanici}

Prkić, Giannuzzi-Savelli \& Pusateri n. sp.

(Figs 10A-F; 11A-E; 12A, B; 16A)

urn:Isid:zoobank.org:act:1DA03143-93D0-4960-A911-DFCD255CDB71

Raphitoma sp. A - Russini et al. 2020: 301.

TYPE MATERIAL. - Holotype. Croatia • lv; MNHN-IM-2000-34890

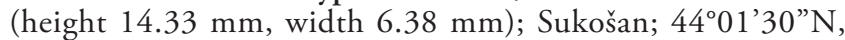
$15^{\circ} 20$ '50"E; 2-6 m depth.

Paratypes. Croatia • 1 lv; MNHN-IM-2000-34891; Brač Island - 5 lv; coll. PRK; same locality data as holotype 1 lv; coll. PUS2801; Brač Island 1 lv; coll. RGS-120249; same locality data as holotype $\bullet 6$ lv; coll. STA; Brač Island • 2 lv; BAU-2256.2, BAU2256.3; same locality data as holotype.

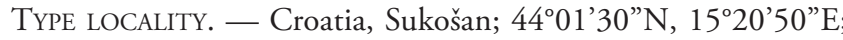
2-6 m depth.

OTHER MATERIAL EXAMINED. - Croatia 4 sh; coll. PRK; Rivanj Island; 20-30 m depth • 4 lv, 2 sh; coll. PRK; Sukošan; 4401'30"N

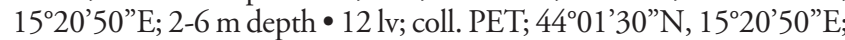

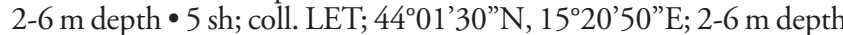
- $5 \mathrm{lv}$; coll. PET; Biograd, Bošana; $1-2 \mathrm{~m}$ depth $\bullet 1 \mathrm{lv}$; coll. PET; Tribunj; $2 \mathrm{~m}$ depth $\bullet 1$ lv; coll. PET; Stari Trogir; $2 \mathrm{~m}$ depth $\bullet 1$ sh; coll. PRK; Voluja • 8 lv; coll. STA; Brač Island, Milna; 8-20 m depth. Sicily $\bullet 8$ sh; MCZR-M-16899; Gulf of Palermo.

Distribution. - Only known from the material examined, in Croatia and in Sicily.

ETYMOLOGY. - After Rino Stanić, for his great contribution to the study of the Croatian molluscs and to the present paper.

HABITAT. - This species has been collected on rocky bottoms with plenty of small and medium-sized stones, on the underside of which the specimens are found at daytime. This is a shallow-water species, most of the live specimens were found at 2-8 $\mathrm{m}$ depth, only a few of them were found at 15-20 m depth (R. Stanić, personal communication). R. stanici Prkić, Giannuzzi-Savelli \& Pusateri n. sp. often lives in sympatry/syntopy with other raphitomids (Cyrillia linearis, Leufroyia leufroyi, L. concinna, Raphitoma contigua, $R$. cordieri AA., $R$. densa, $R$. echinata AA. - morphotype 2 [see below], $C$. cf. ephesina, $R$. laviae, $R$. cf. locardi, $R$. petanii Prkić, Giannuzzi-Savelli \& Pusateri n. sp., $R$. cf. smriglioi, etc.), sometimes with specimens of 5-6 different species occurring under the same stone.

DESCRIPTION [in square brackets the data of the holotype] Shell

Robust and broad, of medium size for the genus. Height: 10.56-19.42 mm [14.33]; width: 5.34-9.17 mm [6.38]; h/d: $1.83-2.3[2.3]$.

\section{Protoconch}

Multispiral with 2.1 to 2.5 [2.3], convex whorls and large nucleus (d: $150 \mu \mathrm{m})$. Protoconch I of 1.2 whorls, $230 \mu \mathrm{m}$ in diameter, covered by dense cancellate sculpture; protoconch II with well-spaced axial threads under the suture extending as low as to mid-height of whorl, and diagonally cancellate sculpture on the rest of whorl. A short and narrow keel at the end of last whorl. Protoconch-teleoconch boundary of flexuose, opisthocline growth lines. Colour usually dark brown or blackish, with or without white nucleus, occasionally entirely very light cream or very light brownish.

\section{Teleoconch}

Of 6.05-7.7 [7.1] convex whorls, suture incised, sculpture very prominent, whole surface covered with extremely fine and dense microgranules. Axial sculpture of 13-18 [14] strong, equidistant, orthocline or slightly opisthocline ribs, much broader than spiral cords, slightly narrower than interspaces. Spiral sculpture of 15-19 [17], spiral cords on the last whorl, of which 5-7 [7] primary cords, above the aperture, first adapical always weaker than second one, starting only at third/fourth whorl; one very weak secondary cordlet on subsutural ramp, with small tubercles at intersection with axial ribs, usually connected by very thin threads. Occasionally on last $0.5-1.5$ whorls $1-4$ secondary cordlets between primary cords, weak to quite evident. Below periphery 2-4 [2] cords, clearly separated from cords on siphonal fasciole by a wide interspace. Siphonal fasciole with 7-9 [8] nodulose cords, often relatively thin and well-spaced. Cancellation varying from rectangular to squared even on same shell, with very elongate and highly elevated tubercles at the intersections; tubercles on first 3-4 adapical primary cords always spinulose. Subsutural ramp wide and inclined, dark brown or black, with broad white comma-shaped lines. Columella simple, straight and slightly inclined to the right anteriorly, strongly angled posteriorly. Siphonal canal short and widely open at the end, posterior channel wide and relatively shallow. Outer lip with 9-10 [9] strong plicate inner denticles.

\section{Colour}

Background colour brown, brown-reddish or grey-blackish, usually darker in the interspaces and on the ramp; light areas, cream, yellowish or light brownish sparse on the shell; a darker band below the periphery. Broad, curved, comma-shaped whitish lines in most interspaces.

\section{Soft parts}

Foot long and broad, deeply bilobed anteriorly and with recurved anterolateral corners, narrowly tapering posteriorly. Head small with a pair of long cylindrical tentacles, black eyes on bulges about halfway along their length, distal part slightly longer and much narrower than basal. Colour translucent yellow or yellowish-white, with minute white speckles covering the whole body, including proximal part of tentacles. Siphon black, often with white speckles on the tip. Small greyish areas occasionally present on head, just behind or below tentacles, sometimes extending from mouth area toward the edge of anterior part of foot.

\section{Diagnostic nucleotides}

91, 331, 448, 592, 625 (COI), and 304, 348, 357, 358 (ITS2). 


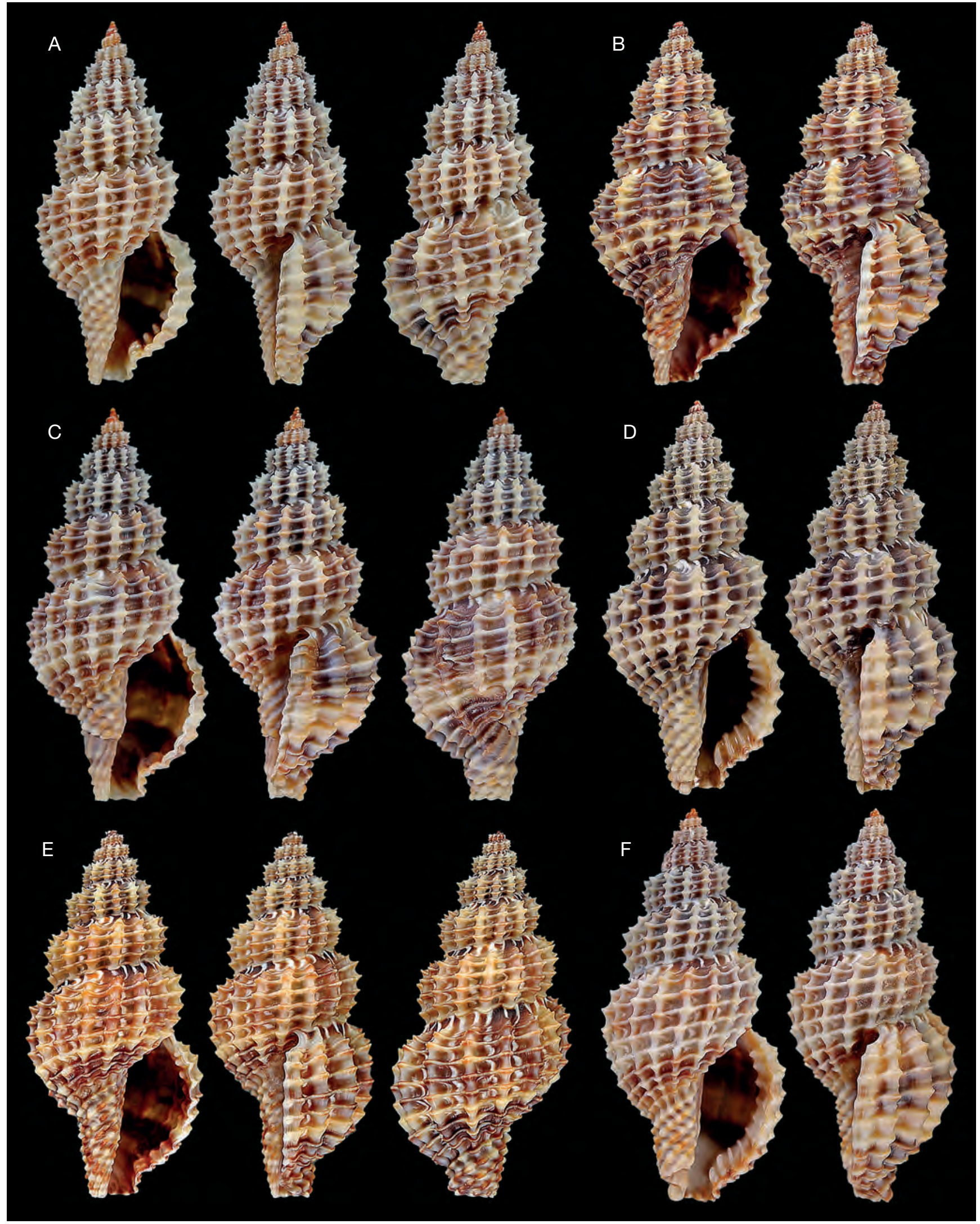

FIG. 10. - Raphitoma stanici Prkić, Giannuzzi-Savelli \& Pusateri n. sp.: A, holotype, MNHN-IM-2000-34890, 14.3 mm, Sukošan; B, paratype, coll. STA, 14.5 mm, Brač Is.; C, paratype, coll. RGS 120249, 16.1 mm, Sukošan; D, paratype, coll. PRK, 16.5 mm, Sukošan; E, paratype, coll. PUS 2801, 14.3 mm, Brač Is.; F, paratype, coll. PRK, $17.1 \mathrm{~mm}$, Sukošan. 


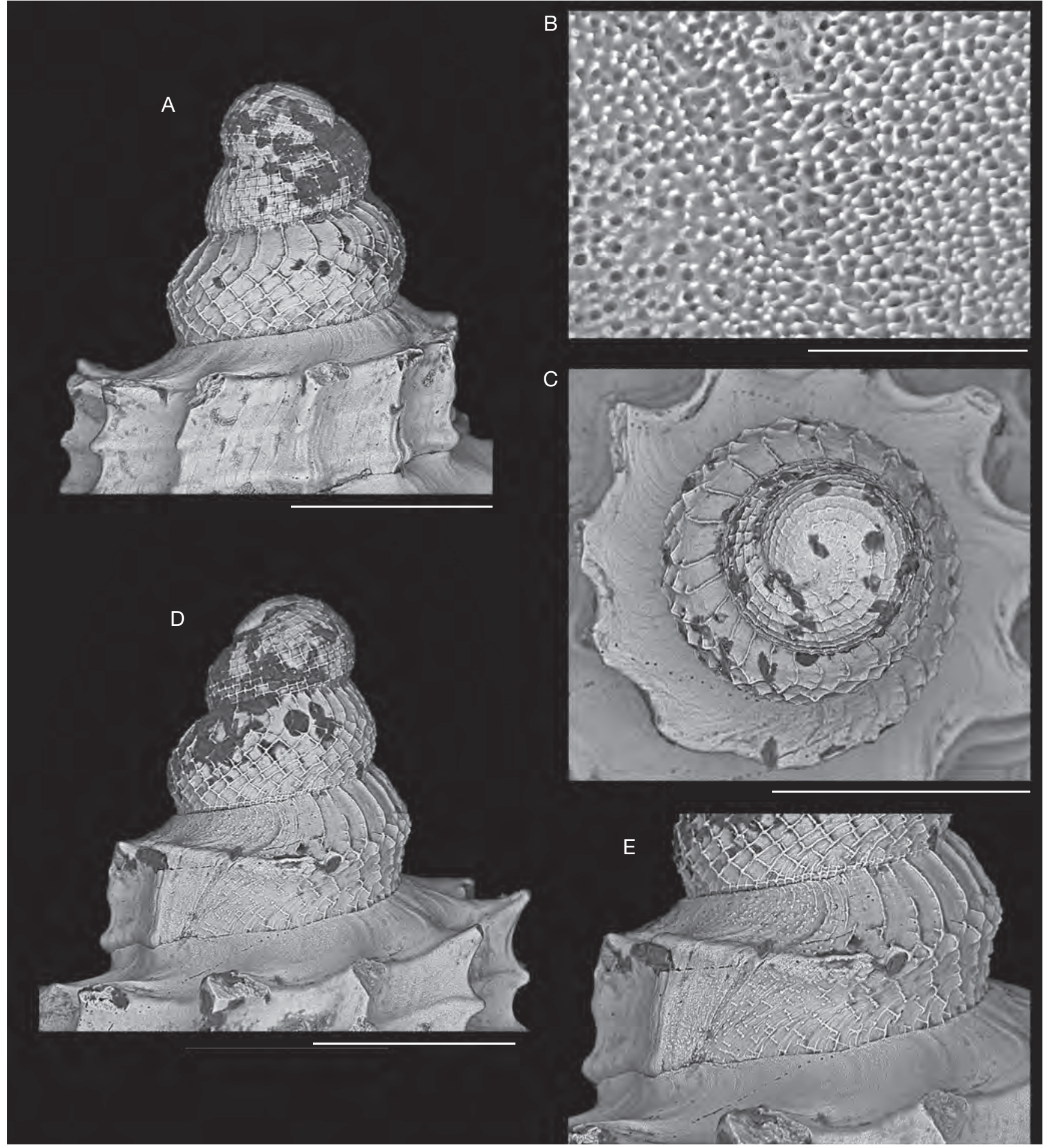

FIG. 11. - Raphitoma stanici Prkić, Giannuzzi-Savelli \& Pusateri n. sp., Brač Island, paratype 13, MNHN, 12.4 mm: A, dorsal view of protoconch; B, detail of microgranules; C-D, apical and frontal view of protoconch; $\mathbf{E}$, detail of transition from protoconch to teleoconch. Scale bars: A, C-E, $300 \mu \mathrm{m}$; B, $20 \mu \mathrm{m}$.

\section{REMARKS}

The height and maximum diameter of protoconch depend on the number of whorls: in the photographed specimen (Fig. 11A-E) with PW $=2.5$ these two features are: $\mathrm{H}=507 \mu \mathrm{m}$ and max. $\mathrm{D}=412 \mu \mathrm{m}$. The protoconch is often very small, with just a little over two whorls, in such cases its profile is more cylindrical due to a large nucleus.

When the secondary cordlet on the subsutural ramp is very weak there are always nine denticles and the uppermost one is placed under the interspace between first and second primary 

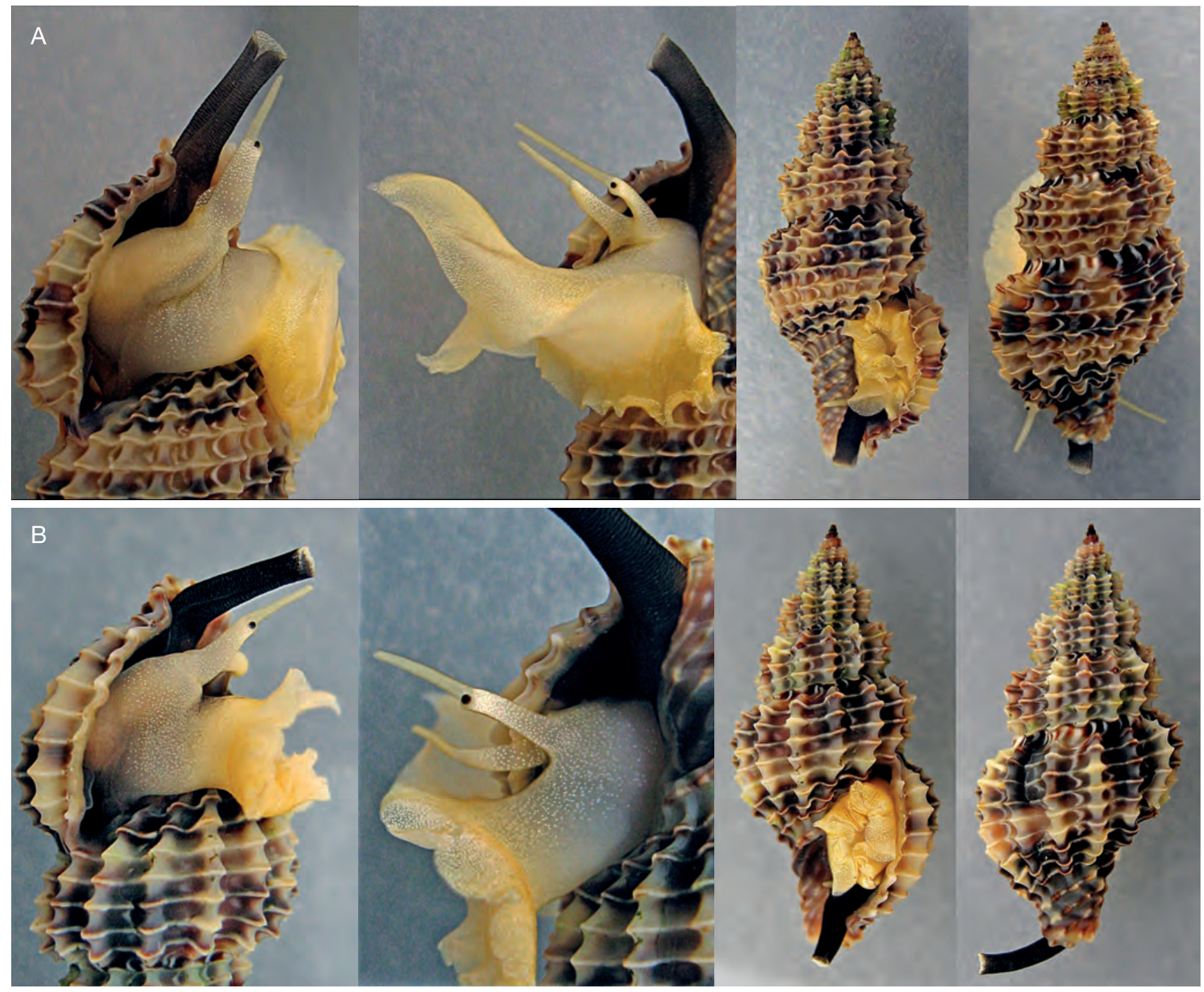

FIG. 12. - A, B, live specimens of Raphitoma stanici Prkić, Giannuzzi-Savelli \& Pusateri n. sp.: A, Sukošan, depth 3-5 m, 19.4 mm; B, Biograd, depth 2 m, $16.1 \mathrm{~mm}$. Photos courtesy: A. Petani.

cords. In the cases when the secondary cordlet is somewhat stronger there is an additional small denticle placed under the interspace between this secondary cordlet and first primary cord; in such cases the number of denticles is always 10 .

After a few years from the time of collecting the shells may look significantly different from fresh ones, especially since the dark colours fade out and the whole coloration becomes lighter.

At low magnification the surface looks like sandpaper with ultra-fine microgrits. The extremely fine microgranules on teleoconch surface (Fig. 11B) are similar in size and density to those of the recently described Raphitoma zamponorum Horro, Gori \& Rolán, 2019 from São Tomé, which differs in the longer protoconch (over 3 whorls vs 2-1-2.5 whorls in $R$. stanici Prkić, Giannuzzi-Savelli \& Pusateri n. sp.), the higher h/d ratio (2.6 vs 1.8-2.3 in $R$. stanici Prkić, GiannuzziSavelli \& Pusateri n. sp.), the fewer axials (11 vs 13-18 in R. stanici Prkić, Giannuzzi-Savelli \& Pusateri n. sp.).
We have found no clear phylogenetic affinity for $R$. stanici Prkić, Giannuzzi-Savelli \& Pusateri n. sp. among the other assayed species of Raphitoma, with genetic divergence from the other species ranging from $7 \%$ to $12 \%$. Morphologically, $R$. stanici Prkić, Giannuzzi-Savelli \& Pusateri n. sp. may resemble the complex of species referable to $R$. echinata (Brocchi, 1814), which were unfortunately not available for DNA analyses.

The types of Murex echinatus Brocchi, 1814 consist of three inventoried specimens (Museo Civico di Storia Naturale, Milano), with numbers i5427, i5428 and i5429, from the Pliocene (Piacentian) of Italy. The first of them was designated by Pinna \& Spezia (1978: 148) as the "holotype" and the two others as the "paratypes". According to the ICZN (1999: art. 74.6), in this case Pinna \& Spezia actually designated a "lectotype" leaving the other two as "paralectotypes". However, the three syntypes belong to 3 different entities. The "lectotype" i5427 (Figs 13A; 15A) (h: 21.6 mm, d: 


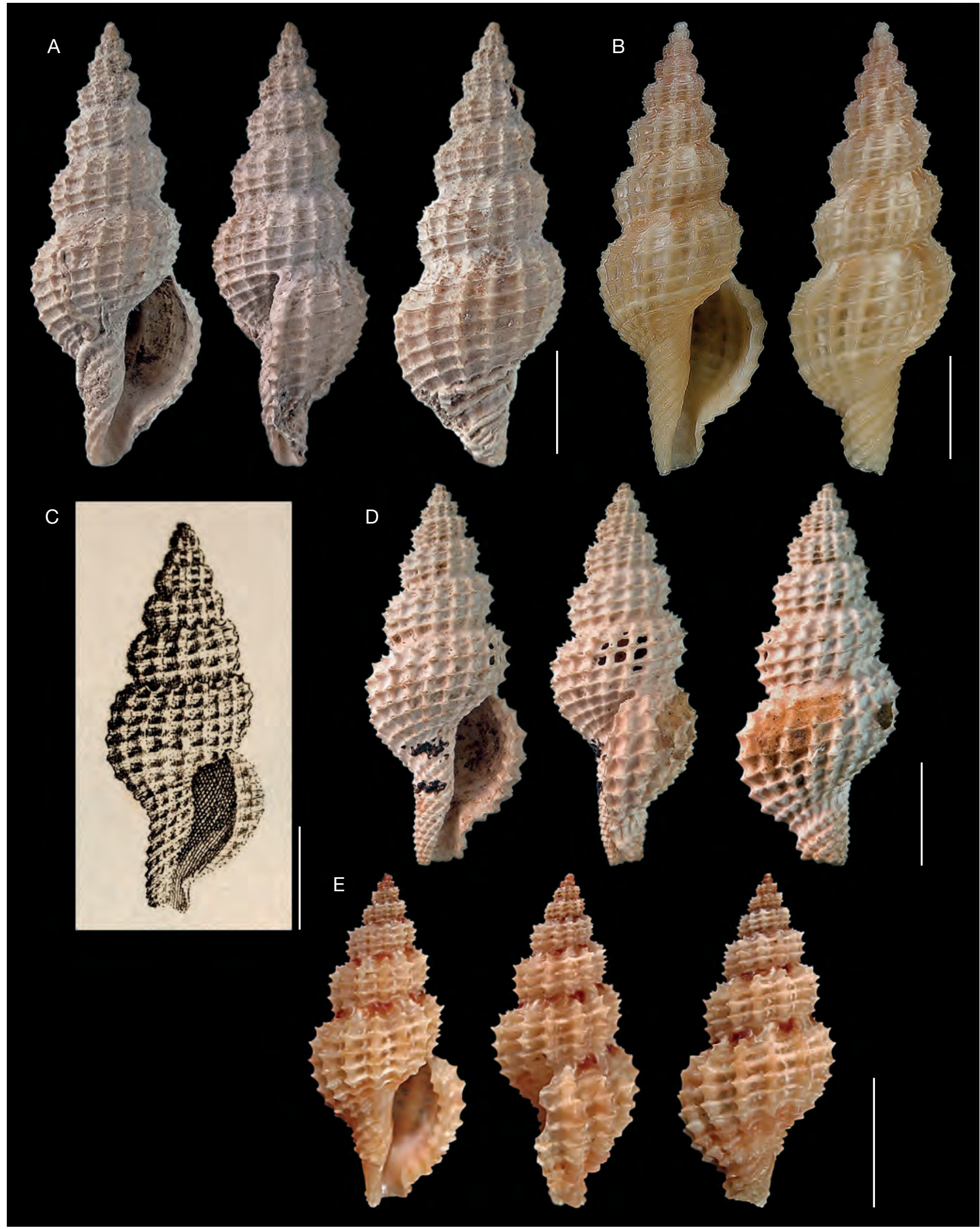

FIG. 13. - A, Murex echinatus Brocchi, 1814, lectotype, MCSNM i5427, 21.6 mm; B, Raphitoma cordieri (Payraudeau, 1826), 22.0 mm, Capraia Is., Italy; C, after Brocchi (1814: fig. 3), 19.0 mm; D, Murex echinatus Brocchi, 1814, paralectotype, MCSNM i5428, 18.6 mm; E, Raphitoma echinata sensu Auctores - morphotype 1, $13.0 \mathrm{~mm}$, Mljet Is., Croatia. Scale bars: $5 \mathrm{~mm}$. A, D: photo courtesy by Michele Zilioli (MCSNM). 


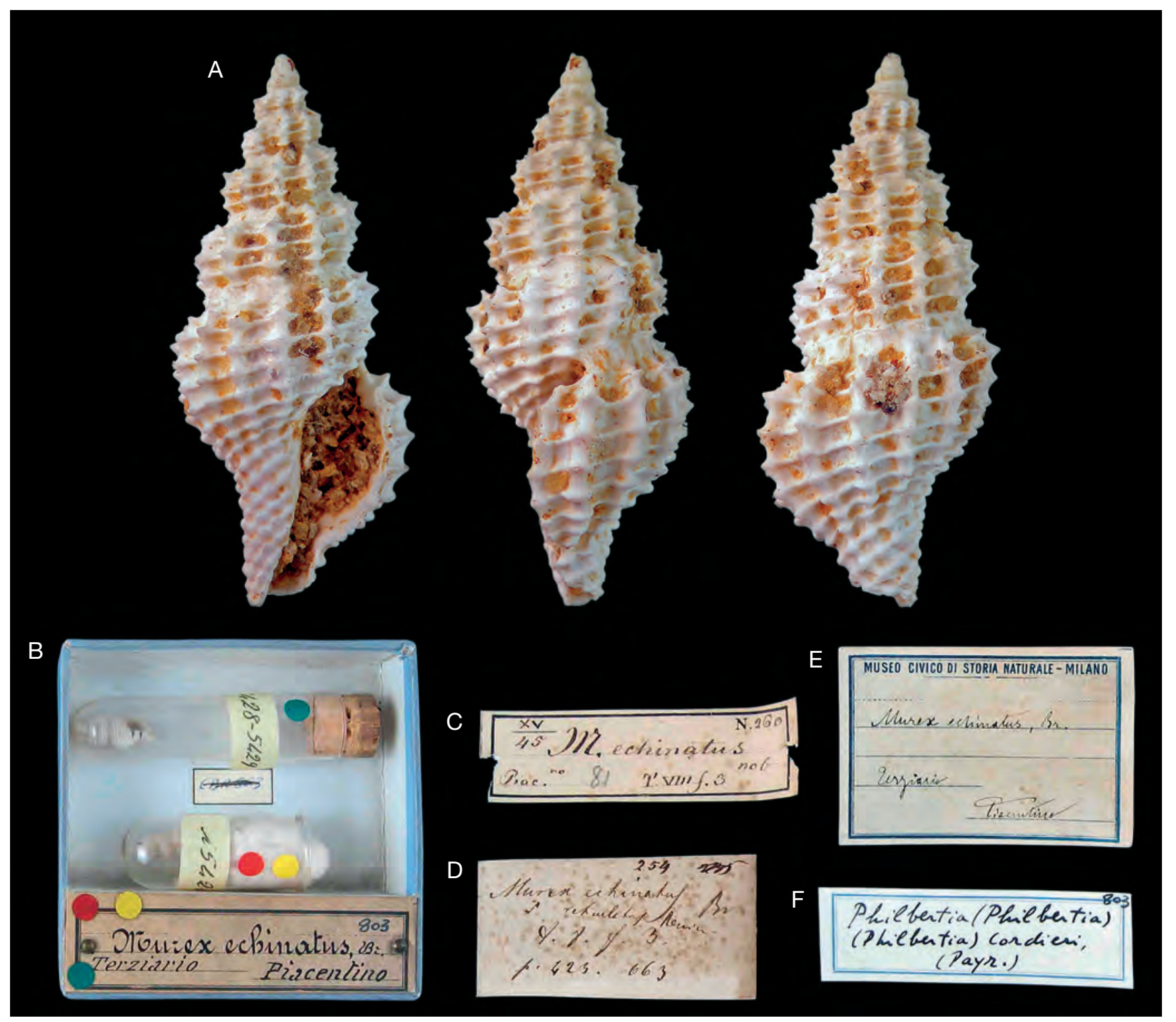

FIG. 14. - Murex echinatus Brocchi, 1814: A, paralectotype, MCSNM i5429, 6.67 mm; B, box of types; C, probable Brocchi's original label; D, E, museum labels; F, label written by Rossi Ronchetti. Scale bar: $3 \mathrm{~mm}$. Photos courtesy: Michele Zilioli (MCSNM).

$8.38 \mathrm{~mm}, \mathrm{~h} / \mathrm{d}: 2.58)$ refers to the species that recent authors identify as $R$. cordieri (Payraudeau, 1826). Rossi Ronchetti (1955) also identified this specimen as Philbertia cordieri (Fig. 14F). Based on its small size, the fine microgranulation covering the entire shell, the very strong sculpture, and the two denticles adjacent to the posterior siphon more robust than the others, the paralectotype i5429 (Figs 14A; 15C, E) (h: $6.67 \mathrm{~mm}, \mathrm{~d}: 2.96 \mathrm{~mm}, \mathrm{~h} / \mathrm{d}: 2.25)$, refers to a species of the group of Cyrillia linearis (Montagu, 1803). The "paralectotype" i5428 (Figs 13D; 15B, D) (h: $18.61 \mathrm{~mm}$, d: $7.93 \mathrm{~mm}, \mathrm{~h} / \mathrm{d}: 2.35)$ is the only one that corresponds quite well to the figure of Brocchi (Fig. 13C), his description and the currently accepted concept of $R$. echinata. Also, its size is close to that reported by Brocchi $(1814 ; 9$ lines $=19 \mathrm{~mm})$. There are many interpretations of Brocchi's taxon in the literature and various morphs or species have been identified as $R$. echinata. We suspect that under the nominal taxon
"R. echinata" of authors a complex of distinct species may be concealed. Pending a revision of the complex based on DNA data, and an extensive study of fossil material (where possibly some nomenclatorial ruling will be necessary), we refer here to the known morphotypes, which may correspond or not to biological species but remain as clear reference for subsequent investigations. Two of them occur in Croatia and are worthy of comparison with $R$. stanici Prkić, Giannuzzi-Savelli \& Pusateri n. sp.: R. echinata morphotype 1 (Fig. 13E), the most similar to paralectotype i5428, and so far known only from Croatia, and $R$. echinata morphotype 2 (Figs 16D; 17).

$R$. echinata morphotypes 1 and 2 share with $R$. stanici Prkić, Giannuzzi-Savelli \& Pusateri n. sp. some morphological features: medium size for the genus; multispiral protoconch; short siphonal canal; 9-10 denticles on the outer lip; strong teleoconch sculpture with more or less spinulose tubercles and axial ribs broader than the spiral cords; 14-20 axial ribs; 

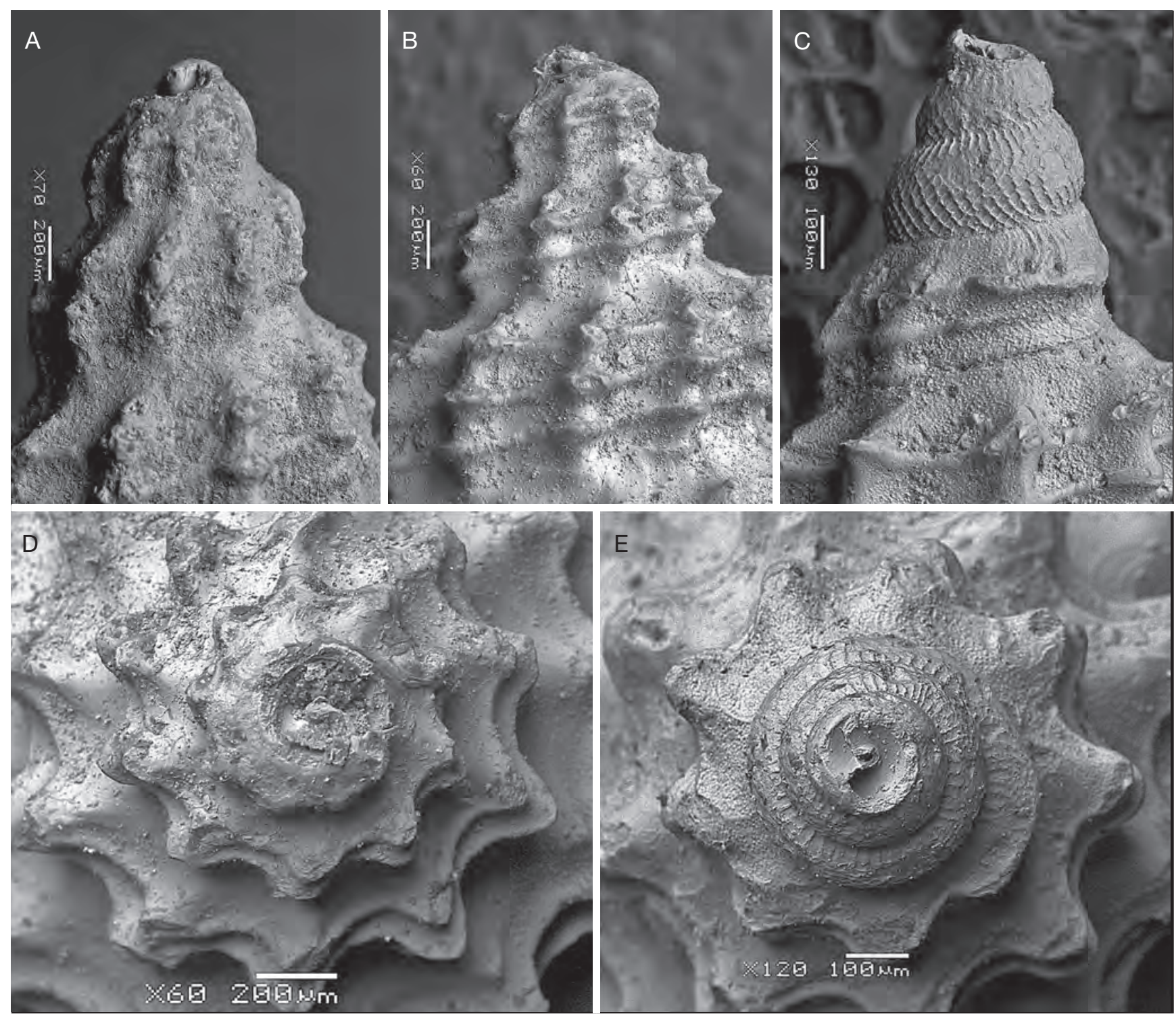

FIG. 15. - Murex echinatus Brocchi, 1814: A, lectotype, MCSNM i5427; B, D, paralectotype, MCSNM i5428; C, E, paralectotype, MCSNM i5429. Photos courtesy: Martina Paolini (MCSNM).

5-6 primary spiral cords above the aperture; 3-4 spiral cords below the periphery of the last whorl, which are always well separated from the cords on the siphonal fasciole; 7-9 cords on the siphonal fasciole; wide subsutural ramps with broad white comma-shaped lines; similar colour pattern with broad and curved white lines in the interspaces; microscopic and extremely dense granules that cover the whole surface of the teleoconch.

Paralectotype i5428 of Murex echinatus also shows most of these features: medium size for the genus; short siphonal canal; 10 denticles on the outer lip; strong teleoconch sculpture with spinulose tubercles and axial ribs much larger than the spiral cords; 20 axial ribs; six primary spiral cords above the aperture; three spiral cords below the periphery of the last whorl which are well spaced from the cords on the siphonal fasciole; nine cords on the siphonal fasciole. The colour pattern is unknown in this fossil shell and the protoconch is missing.
R. stanici Prkić, Giannuzzi-Savelli \& Pusateri n. sp. differs from paralectotype i5428 in the more robust aspect of the shell, stronger and less numerous axial ribs [13-18 (mean 15.19) vs 20], broader shell [h/d: 1.83-2.25 (mean 2.05) vs 2.35 ], wider aperture, wider subsutural ramps, presence of microscopic granules, which are absent in paralectotype i5 5428 .

R. stanici Prkić, Giannuzzi-Savelli \& Pusateri n. sp. differs from $R$. echinata morphotype 1 in the darker colour pattern of the shell, the more robust aspect, the wider aperture, the smaller number of protoconch whorls [2.1-2.5 (mean 2.32) vs 3.1-3.35 (mean 3.28)].

R. stanici Prkić, Giannuzzi-Savelli \& Pusateri n. sp. differs from R. echinata morphotype 2 in the broader shell, the more elevated and more spinulose tubercles, the wider subsutural ramps, the smaller number of protoconch whorls $(2.1-2.5 \mathrm{vs}$ 2.7-3.3), the smaller number of teleoconch whorls at the same 


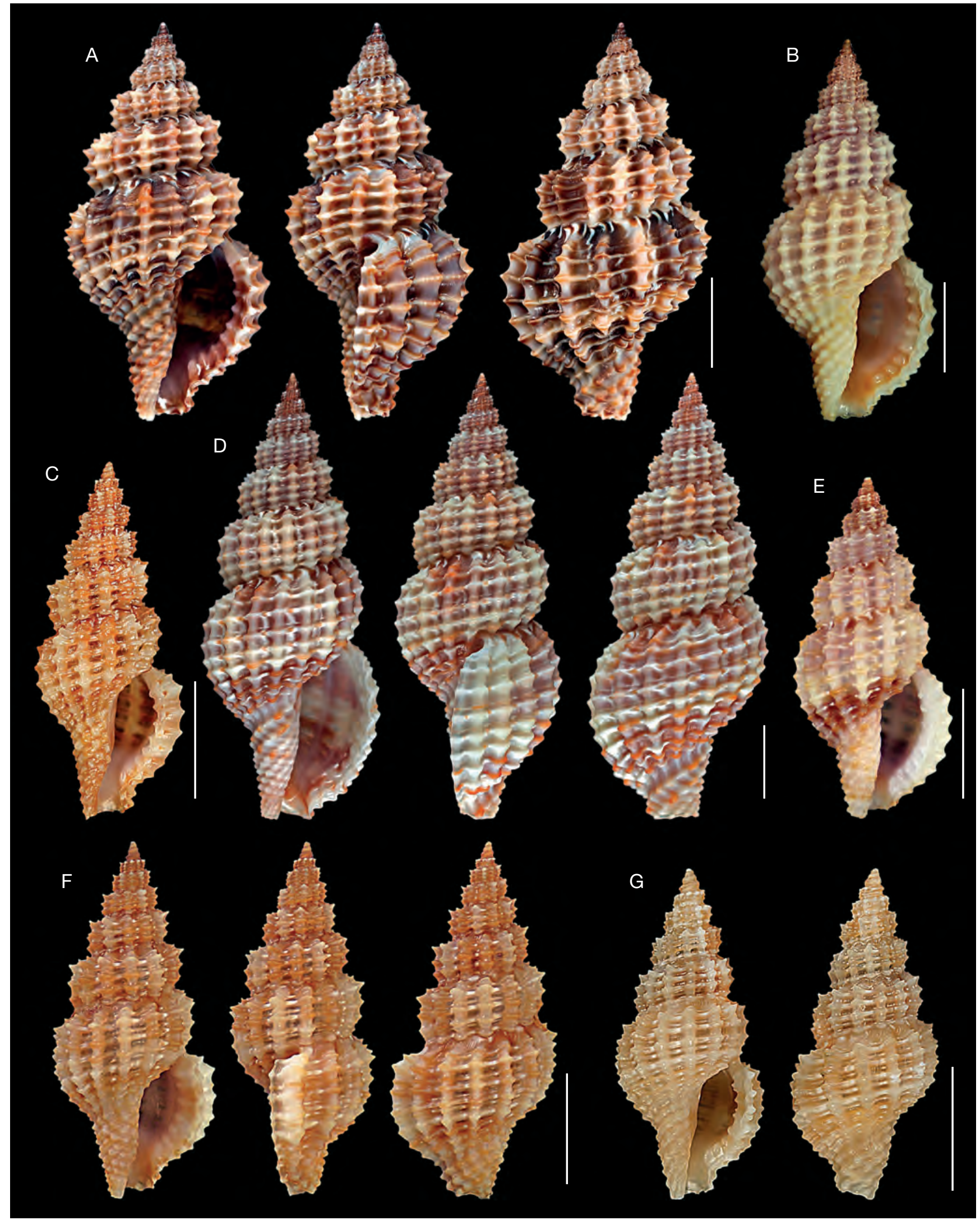

FIG. 16. - A, Raphitoma stanici Prkić, Giannuzzi-Savelli \& Pusateri n. sp., paratype, coll. STA, $13.22 \mathrm{~mm}$, Brač Is., Croatia; B, R. echinata sensu Auctores - morphotype 3, 12.7 mm, Le Grau du Roi, France; C, R. echinata AA. - morphotype 4, 9.2 mm, Saronic Gulf, Greece; D, E, R. echinata AA. - morphotype 2: D, 18.3 mm, Sevid, Croatia; E, 9.55 mm, Saronic Gulf, Greece; F, G, R. echinata AA. - morphotype 5: F, 9.4 mm, Saronic Gulf, Greece; G, 8.0 mm, Alboran Sea, Spain. Scale bars: $3 \mathrm{~mm}$. Photos courtesy: E, F, Kontadakis. 


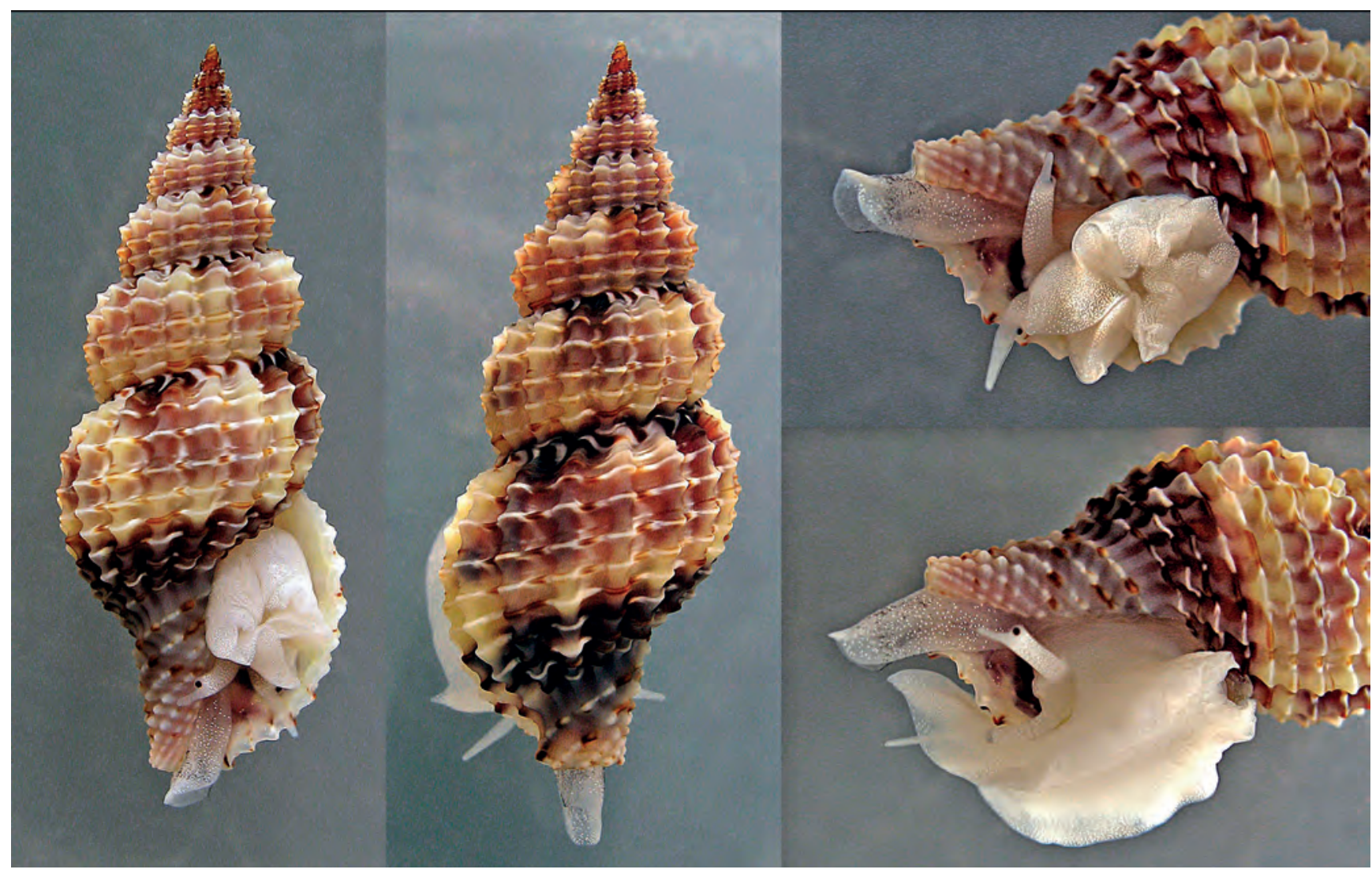

FIG. 17. - Live specimen of Raphitoma echinatasensu Auctores - morphotype 2, Sevid, Croatia, depth 5 m, 18.3 mm

shell size (e.g. for $\mathrm{h}=18.3 \mathrm{~mm}$ TW is 7.5 vs 8.5 ), the absence of pinkish areas on the teleoconch which are always present in fresh shells of the morphotype 2 . They differ also in the colour pattern of the animal, the animal in morphotype 2 (Fig. 17) being always completely white except for some scattered grey speckles occasionally present on the siphon.

\section{Acknowledgements}

We thank Neven Lete and Rino Stanić for making the specimens from their collections available for this study. A special thanks to Alen Petani who collected most of the specimens of $R$. petanii Prkić, Giannuzzi-Savelli \& Pusateri n. sp. and took many photos of living animals. We are indebted to Stefano Bartolini, A. Petani, Pero Ugarković and Constantinos Kontadakis for the colour photos of the shells, to Andrea Di Giulio for the SEM images of $R$. densa, to Michele Zilioli and Martina Paolini for the colour and SEM images of the syntypes of $M$. echinatus, to Gianni Repetto for bibliographic help and Carlo Smriglio for his kind collaboration. Philippe Bouchet and Alexander Fedosov provided very useful criticisms to a previous version of this paper. Work supported by Sapienza grants to VR (AR11715C7E17226C) and to MO (RM11715C818F7955), and by Associazione Naturama (Palermo). The MNHN gives access to the collections in the framework of the RECOLNAT national Research Infrastructure.

\section{REFERENCES}

Bellardi L. 1847. - Monografia delle Pleurotome fossili del Piemonte. Memorie della Reale Accademia delle Scienze di Torino serie 2, 9: 531-650, 4 pls. https://doi.org/10.5962/bhl.title.58977

Bellardi L. 1875. - Novae pleurotomidarum Pedimonti et Liguriae fossilium: dispositionis prodromus. Bullettino della Società Malacologica Italiana 1: 16-24.

Bouchet P., Kantor Y. I., Sysoev A. \& Puillandre N. 2011. A new operational classification of the Conoidea (Gastropoda). Journal of Molluscan Studies 77 (3): 273-308. https://doi. org/10.1093/mollus/eyr017

BrocCHI G. B. 1814. - Conchiologia fossile subapennina, con osservazioni geologiche sugli Apennini e sul suolo adiacente. Stamperia Reale, Milano Vol. II: 241-712, pls 1-16. https://doi. org/10.5962/bhl.title.11569

Brown S. D., Collins R. A., Boyer S., Lefort M.-C., MalumbresOlarTe J., Vink C. J., \& CRUICKSHANK R. H. 2012. — Spider: an $\mathrm{R}$ package for the analysis of species identity and evolution, with particular reference to DNA barcoding. Molecular Ecology Resources 12 (3): 562-565. https://doi.org/10.1111/j.1755-0998.2011.03108.x

BRUSINA S. 1865. - Conchiglie dalmate inedite (circa 90 specie). Verhandlungen der Kaiserlich-königlichen Zoologisch-botanisch Gesellschaft in Wien 15: 3-42.

BRUSINA S. 1866. - Contribuzione pella fauna dei Molluschi dalmati. Verhandlungen der Kaiserlich-königlichen zoologischbotanischen Gesellschaft in Wien 16: 1-134, 1 pl.

BRUSINA S. 1872-1908. - Naravoslovne crtice sa sjevero-istočne obale Jadranskoga mora. Rad Jugoslavenske akademije znanosti i umjetnosti, Zagreb Knj. 19 (1872): 105-177, Knj. 27 (1874): 131-193, Knj. 38 (1905): 1-40, Knj. 41 (1907): 195-251, Knj. 42 (1907): 43-228, Knj. 43 (1908): 1-31. 
Chemonics InTERnATIONAL INC. 2000. — Biodiversity assessment for Croatia. Natural Resource Management and Development Portal. https://rmportal.net/library/content/118_croatia/view

Chester C., Agosti D., Sautter G., Catapano T., Martens K., GÉrARD I. \& BéNICHOU L. 2019. - EJT editorial standard for the semantic enhancement of specimen data in taxonomy literature. European Journal of Taxonomy 586: 1-22. https://doi. org/10.5852/ejt.2019.586

Coen G. S. \& Vatova A. 1932. - Malacofauna arupinensis. Thalassia 1: 1-53.

Crosse H. 1885. - Nomenclature generica e specifica di alcune Conchiglie Mediterranee, pel marchese di Monterosato [book review]. Journal de Conchyliologie 33: 139-142.

DANILO F. \& SANDRI G. B. 1855. - Elenco nominale dei molluschi lamellibranchiati marittimi raccolti nei contorni di Zara. Nel programma dell'I. R. Ginnasio di Zara, 20 p.

DANILO F. \& SANDRI G. B. 1856. - Elenco nominale dei gasteropodi testacei marini raccolti nei dintorni di Zara, e determinati dal Sig. Giovanni Battista Sandri e dal Prof. Dr. Francesco Danilo. Programma dell'I. R. Ginnasio completo di prima classe in Zara alla fine dell'anno scolastico 1855-1856: 107-150.

Fassio G., Russini V., Pusateri F., Giannuzzi-Savelli R., HøisÆter T. \& Puillandre N. 2019. - An assessment of Raphitoma and allied genera (Gastropoda, Conoidea, Raphitomidae). Journal of Molluscan Studies 85 (4): 414-425.

FISCHER P. 1883. - Diagnoses d'espèces nouvelles de mollusques recueillis dans le cours des expéditions scientifiques de l'aviso le Travailleur (1882).-Pars II. Journal de Conchyliologie 30: 273-277.

GiannuZzi-SaVelli R., Pusateri F., Bartolini S. \& Oliverio M. 2017. - A revision of the Mediterranean Raphitomidae (Neogastropoda, Conoidea) 4: The species of the group of Raphitoma purpurea (Montagu, 1803) with the description of a new species. Bollettino Malacologico 53: 161-183.

GiANNUZZI-SAVELli R., PUSATERI F. \& BARTOLINI S. 2018a. - A revision of the Mediterranean Raphitomidae (Gastropoda, Conoidea), 7: on the sibling species Raphitoma densa (Monterosato, 1884) and $R$. griseomaculata n. sp. Biodiversity Journal 9 (4): 429-440. https://doi.org/10.31396/Biodiv.Jour.2018.9.4.429.440

Giannuzzi-Savelli R., Pusateri F. \& Bartolini S. 2018b. A revision of the Mediterranean Raphitomidae (Gastropoda Conoidea), 5: Loss of planktotrophy and pairs of species, with the description of four new species. Bollettino Malacologico 54 Suppl. 10: 1-77.

Harris G.F. \& Burrows H.W. 1891. - The Eocene and Oligocene Beds of the Paris Basin. Geological Association of London, London, viii + 129 p. https://doi.org/10.5962/bhl.title.13964

Ilijanić V. \& STOŠIĆ M. 1972. — Popis zbirke mekušaca (Mollusca) Spiridiona Brusine. Hrvatski Narodni Zoološki Muzej, Zagreb, 86 p.

KANTOR Y. I. \& TAYLOR J. D. 2002. — Foregut anatomy and relationships of raphitomine gastropods (Gastropoda: Conoidea: Raphitominae), in Oliverio M. \& Chemello R. (eds), Systematics, Phylogeny and Biology of the Neogastropoda. Bollettino Malacologico Supplement 5: 161-174.

KLEĆAK B. 1873. - Catalogus ad rationem synonymion ordinatus ma rinorum molluscorum Dalmatiae, qua ut inter opera artificiaque propalara collocanda ponerentur anno 1873 Vindobonam mittit Blasius Klecak. Spalati, Typis Antonii Zannoni, 44 p.
Kontadakis C., Mbazios G., Polyzoulis G. \& Manousis T. 2019. Two new species of Raphitoma (Gastropoda: Conoidea: Raphitomidae) from the Greek Seas. Xenophora Taxonomy 25: 26-36.

Monterosato T. DI M. 1872. - Notizie Intorno alle Conchiglie Mediterranee. Michele Amenta, Palermo, 61 p. https://doi. org/10.5962/bhl.title.50743

MonTEROSATO T. DI M. 1884. - Nomenclatura generica e specifica di alcune conchiglie mediterranee. Stabilimento Tipografico Virzi, Palermo, 152 p. https://www.biodiversitylibrary.org/page/35367233

PinNa G. \& SPEZIA L. 1978. - Catalogo dei tipi del Museo Civico di Storia Naturale di Milano. V. I tipi dei Gasteropodi fossili. Atti della Società Italiana di Scienze Naturali e del Museo Civico Storia Naturale di Milano 119 (2): 125-180.

Pusateri F., Giannuzzi-Savelli R. \& Oliverio M. 2012. A revision of the Mediterranean Raphitomidae 1: on the sibling species Raphitoma contigua Monterosato, 1884 and Raphitoma spadiana n. sp. (Gastropoda, Conoidea). Iberus 30 (1): 41-52.

Pusateri F., GiannuZZi-SAVElli R. \& Oliverio M. 2013. - A revision of the Mediterranean Raphitomidae. 2. On the sibling species Raphitoma lineolata (B.D.D., 1883) and Raphitoma smriglioi n. sp. Iberus 31 (1): 11-20.

Pusateri F., GiannuZZi-SAVElli R. \& BARTOlini S. 2016. - A revision of the Mediterranean Raphitomidae. 3. On the Raphitoma pupoides (Monterosato, 1884) complex, with the description of a new species (Mollusca Gastropoda). Biodiversity Journal 7 (1): 103-115.

Puillandre N., Baylac M., Boisselier M., Cruaud C. \& SAmadi S. 2009. - An integrative approach to species delimitation in Benthomangelia (Mollusca: Conoidea). Biological Journal of the Linnean Society (96): 696-708. https://doi.org/10.1111/j.10958312.2008.01143.x

Pusateri F., GianNuZZi-SAVELli R. \& BARTOLINI S. 2018. - A revision of the Mediterranean Raphitomidae (Gastropoda Conoidea), 6: on the Raphitoma corbis (Potiez et Michaud, 1838). Biodiversity Journal 9 (3): 217-225.

ROMANi L., RAVEGgi A., SCAPERROTTA M. \& BARTOLINI S. 2018. Contributo alla conoscenza della malacofauna marina delle isole adriatiche. 1. Nota sui micromolluschi marini conchiferi rinvenuti sulla costa settentrionale dell' isola di Lastovo [Lagosta] (Croazia, Mar Adriatico Sud-Orientale). Alleryana 36 (1): 1-22.

Rossi RonCHETTI C. 1955. - I tipi della "Conchiologia Fossile Subapennina" di G. Brocchi. Parte II: Gastropodi, Scafopodi. Rivista Italiana di Paleontologia e Stratigrafia, Memorie 5 (2): 91-343.

Russini V., Giannuzzi-Savelli R., Pusateri F., Prkić J., Fassio J., Modica M. V. \& Oliverio M. 2020. - Genetic evidence of poecilogony in the genus Raphitoma Bellardi, 1847. Invertebrate Systematics 34: 293-318. https://doi.org/10.1071/IS19039

STossich A. 1880. - Prospetto della Fauna del Mare Adriatico. Parte II. Mollusca IV. Bollettino della Società adriatica di Scienze naturali in Trieste 5: 236-286.

VERDUIN A. 1976. - On the systematics of recent Rissoa of the subgenus Turboella Gray, 1847, from the Mediterranean and the European Atlantic coasts. Basteria 40: 21-73.

Vio E. \& De Min R. 1999. - I molluschi del litorale marino di Cervera (Parenzo, Istria). Annales (Analiza istrske in mediteranske študije). Series historia naturalis 9 (2): 167-176.

ZAVODNIK D. \& KOVAČIĆ M. 2000. - Index of marine fauna in Rijeka Bay (Adriatic Sea, Croatia). Natura Croatica 9 (4): 297-379. 